\title{
Changes in soil profile hydraulic properties and porosity as affected by deep tillage soil preparation and Brachiaria grass intercropping in a recent coffee plantation on a naturally dense Inceptisol
}

\author{
Rodrigo Fonseca da Silva ${ }^{a}$, Eduardo da Costa Severiano ${ }^{\mathrm{b}, *}$, Geraldo César de Oliveira ${ }^{\mathrm{c}}$, \\ Samara Martins Barbosa ${ }^{d}$, Devison Souza Peixoto ${ }^{c}$, Diego Tassinari ${ }^{c}$, Bruno Montoani Silva ${ }^{c}$, \\ Sergio Henrique Godinho Silva ${ }^{c}$, Moacir de Souza Dias Júnior ${ }^{c}$, \\ Tomás d'Aquino Freitas Rosa Figueiredo ${ }^{\mathrm{e}}$
}

${ }^{a}$ Departamento Engenharia Agronômica, Universidade Federal do Piauí, Campus Professora Cinobelina Elvas, CEP 649000-00 Bom Jesus, Piauí, Brazil

${ }^{\mathrm{b}}$ Instituto Federal de Educação, Ciência e Tecnologia Goiano, Campus Rio Verde, Caixa Postal 66, CEP 75909-290, Rio Verde, Goiás, Brazil

${ }^{c}$ Departamento de Ciência do Solo, Universidade Federal de Lavras, Campus universitário, Caixa Postal 3037, CEP 37200-000, Lavras, Minas Gerais, Brazil

d Universidade Estadual Paulista, Faculdade de Ciências Agrárias e Veterinárias, Câmpus de Jaboticabal, CEP 14884-900, Jaboticabal, São Paulo, Brazil

e Centro de Investigação de Montanha, Instituto Politécnico de Bragança, Campus de Sta Apolónia, 5300-253 Bragança, Portugal

\section{A R T I C L E I N F O}

\section{Keywords:}

Soil hydrodynamic attributes

Soil management

Geostatistics

Subsoiling

\begin{abstract}
A B S T R A C T
Soil management operations change soil porosity, affecting water infiltration, redistribution, storage, availability, and uptake by plants. Assessing how soil management may affect pore size distribution and hydraulic conductivity is thus highly relevant for rainfed agriculture coping with water shortage. The aim of this study was to assess the effectiveness of tillage treatments, designed to deepen coffee plants root system, on improving structure and physical-hydric attributes of an Inceptisol with a shallow solum. The study was conducted in an experimental area in the municipality of Nazareno, Minas Gerais State, Brazil. Soil samples were collected 18 months after coffee plantation, at different depths $(0,0.25,0.35,0.45,0.55,0.66$, and $0.75 \mathrm{~m})$ and they were used to determine pore-size distribution, saturated and unsaturated hydraulic conductivity. Samples were also collected in surface crusts or in the $0-0.005 \mathrm{~m}$ soil layer for detailed grain size analysis. Field water infiltration was measured at different water tensions. Coffee seedlings were planted in rows furrowed to depths depending on tillage treatment: $0.4 \mathrm{~m}$ depth, made by a furrow ridger (FP40); $0.6 \mathrm{~m}$ depth, made by a subsoiler coupled to a soil preparer mixing the soil to a depth of $0.6 \mathrm{~m}$ (FP60); $0.8 \mathrm{~m}$ depth, made by a subsoiler and, after mixing the soil to a depth of $0.6 \mathrm{~m}$, by the soil preparer (FP80). The soil between the planting rows was covered by Brachiaria-grass. Soil sampling and field tests were performed in the coffee plants row mechanically treated, in the Brachiaria-grassed inter-row (IR) lane and in a nearby area under natural vegetation (NC). Treatments effects, either mechanical in the coffee rows (FP40, FP 60 and FP80), or biological in the inter-row lane (IR) were compared to reference (NC), representing soil conditions prior to coffee plantation. The FP60 and FP80 treatments improved water infiltration, storage and hydraulic conductivity in the planting rows to a depth of $0.5 \mathrm{~m}$. A more favorable pore size distribution was obtained following these treatments, which improved the soil physical environment. Conversely, furrowing promoted compaction at each implement working depth due to the pressure applied by the rods in the subsurface soil layers, combined with subsoil moisture condition at the time of operations. Root activity of intercropped Brachiaria-grass (IR) improved soil structure, expressed by a favorable pore-size distribution and a faster hydraulic conductivity in the inter-row lane. Similar effects were obtained with FP 60 and FP80 for the coffee rows, where deep furrowing during soil preparation reduced the natural density of the Inceptisol. Therefore, the management strategies tested allowed root deepening and access to soil moisture stored in deeper layers.
\end{abstract}

\footnotetext{
* Corresponding author.

E-mail addresses: rodrigo11.07@hotmail.com (R.F. Silva), eduardo.severiano@ifgoiano.edu.br (E.C. Severiano), geraldooliveira@dcs.ufla.br (G.C. Oliveira),

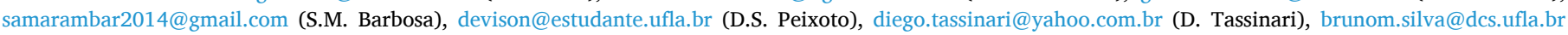
(B.M. Silva), sergio.silva@dcs.ufla.br (S.H.G. Silva), msouzadj@dcs.ufla.br (M.S. Dias Júnior), tomasfig@ipb.pt (T.d'.F.R. Figueiredo).
} 


\section{Introduction}

There is increasing concern for mitigating the impact of global climate change on global food production (Sillmann et al., 2013), and several studies suggested reconverting farmland anthropized and degraded areas, or even land considered marginal for agriculture, through the adoption of management techniques that can enhance deeper soil exploration by crop root systems (Kirkegaard et al., 2007; Serafim et al., 2013a; Silva et al., 2015). This premise is based on the fact that deep soil layers can store considerable amounts of water (Kautz et al., 2013; Wiesmeier et al., 2013; Schneider et al., 2017), eventually available for plants root uptake during water deficit periods.

Brazil is the world's largest producer and exporter of coffee beans (Conselho dos Exportadores de Café do Brasil (CECAFÉ), 2018), and coffee production is concentrated mainly on Oxisols and Ultisols because these soils, when limed and fertilized, are favorable to crop development. Competition with other crops (soybeans and corn) led to widespread cultivation of coffee on soils less suitable for these crops, such as Inceptisols (Bernardes et al., 2012). However, this requires assessing how crop management practices adopted on coffee plantations in such areas may be impairing soil quality. These soils qualify as Cambissolos, according to the Brazilian Soil Classification System, by Santos et al. (2018), as Inceptisols, according to the USA Keys of Soil Taxonomy, by Soil Survey Staff (2014), and as Cambisols according to the World Reference Base for Soil Resources, by International Union of Soil Sciences (IUSS) Working Group WRB, 2015, which estimates a global coverage as important as approximately 1.5 billion hectares worldwide.

In addition, these soils are well represented and widely cultivated with coffee trees in the physiographic zone of Campos das Vertentes, Minas Gerais state, Brazil, which ranks as the country's largest coffee producer (Companhia Nacional de Abastecimento (CONAB), 2017; Barbosa et al., 2020). In this region, Inceptisols usually occur in rougher reliefs and are naturally dense, with shallow solum, thus hindering root growth at deeper soil layers. These characteristics are often combined with a high susceptibility to surface crusting (due to their large silt and fine sand contents), resulting in soils with low infiltration rates and permeability. Overall, such soil attributes limit coffee plants development (Effgen et al., 2012), in addition to favoring surface runoff and soil loss due to water erosion (Mellek et al., 2010; Resende et al., 2014). However, recent studies have shown that the productive potential of areas with Inceptisols can be enhanced by planting coffee trees in deep furrows (Schneider et al., 2017), which, combined with other crop management practices, may result in sizable yields (Serafim et al., 2013b).

Previous studies demonstrated that, although they have a relatively dense soil matrix, Inceptisols might provide available water for coffee plants at deeper soil layers (Serafim et al., 2013b; Silva et al., 2015). In a study on Inceptisols in Minas Gerais state, Brazil, Serafim et al. (2013a) showed that seasonal variation in soil moisture is significant down to $0.80 \mathrm{~m}$ soil depth; below this depth, however, water content is fairly uniform throughout the year. This suggests that improving soil conditions so as to allow deeper root development and thus plant access to deep soil water is likely to pay off in rainfed coffee plantations. Additionally, water recharge of deep soil layers requires the adoption of crop management practices or soil preparation techniques favoring water infiltration and redistribution in soils.

Soil management can change positively soil water dynamic properties. Deep tillage strategies proved to be important in positively impact porosity (Schneider et al., 2017; Peixoto et al., 2019, 2020). Final infiltration rate improved $95 \%$ due to subsoiling and enhanced yield attributes of cotton in the first following cropping season (Singh et al., 2019). Improvements in saturated hydraulic conductivity due to subsoiling led to an increase of $12 \%$ in corn grain yield and $15 \%$ in water use efficiency compared to conventional furrow at $15 \mathrm{~cm}$ (Xie et al., 2020). In a citrus orchard, subsoiling at $0.8 \mathrm{~m}$ depth increased unsaturated hydraulic conductivity, improving fruit number and orchard yield
(Medeiros et al., 2013). However, mechanical alleviation of soil structure can also have negative aspects regarding the soil water dynamics, highlighting a possible soil structure degradation with Ks reduction (Dexter et al., 2004) due to reconsolidations process (Bonetti et al., 2017).

An alternative to limit deleterious effects and maintain the favorable structural change obtained with deep soil management practices is to associate these with cover crops. Cover crops induce changes in pore connectivity (Pulido-Moncada et al., 2020), which is specifically reported by Galdos et al. (2020) for Brachiaria sp., that enhance hydraulic conductivity and water availability in the root-soil interface (Carminati et al., 2016) In fact,. Brachiaria in maize inter-row contributed for increasing saturated hydraulic conductivity by up to five times the values observed in uncultivated maize inter-rows (Scarabeli et al., 2018). However, in spite of the increasing adoption of Brachiaria intercropped with coffee (Serafim et al., 2013a, 2013b), very scarce information exists on its effects on soil hydraulic properties when combined with subsoiling operations during coffee plots installation. As soil water availability to coffee plants is strongly dependent on soil physical attributes (Kahlon et al., 2013; Silva et al., 2015, 2017; Silva et al., 2018, 2019; Barbosa et al., 2020), understanding how different management practices may affect water infiltration, redistribution and storage processes in soils is key for crop development in coffee plantations.

Remarkably, there is a lack of studies on recently installed coffee plantations testing management techniques aimed at overcoming soil physical-hydric constraints that result from their pedogenetic evolution, as it is the case of naturally dense shallow soils. The first two years after plantation are a decisive study period because, on one hand, the crop expresses its maximum production potential in the following years reflecting its development pattern and constraints during that period. On the other hand, environmental issues as soil erosion control and deep soil water recharge, early tackled with improved soil physical-hydric conditions in the coffee plants rhizosphere, is key for sustainable crop water supply during the coffee plantation lifetime.

The research hypothesis was that conditioning the physical status of Inceptisols down to a depth of $0.80 \mathrm{~m}$ for coffee plantation improves the root system environment, positively affecting access to water by coffee plants. This study aimed at assessing changes in porosity and hydraulic properties along the soil profile determined by different soil preparation alternatives for the establishment of a coffee plantation in a shallow Inceptisol. Three planting furrow depths $(0.4,0.6$ and $0.8 \mathrm{~m})$ in coffee plat rows and Brachiaria-grass in the inter-row were compared for their effectiveness in changing hydraulic properties and porosity on naturally restricted rooting conditions. The alternatives tested represent a profile disturbance gradient (from surface light to deep heavy operations) and soil properties assessed describe water dynamics and distribution in the soil profile.

\section{Material and methods}

\subsection{Study site}

The experimental site is located in the municipality of Nazareno $\left(44^{\circ}\right.$ $39^{\prime} 04^{\prime \prime} \mathrm{W}, 21^{\circ} 10^{\prime} 52^{\prime \prime} \mathrm{S}$ ), southern Minas Gerais, southeastern Brazil (Fig. 1). The physiographic region is defined as Campo das Vertentes, the native vegetation including rupestrian fields consisting mainly of grasses of various sizes (Barbosa et al., 2020). Natural fires are common, which reduce plant cover.

The annual precipitation in the region is between 1200 and 1500 $\mathrm{mm}$, and the average annual temperature ranges from 18 to $19^{\circ} \mathrm{C}$ (Peel et al., 2007). The local climate is classified as Cwa according to the Köppen classification system, with rainy, hot summers and dry, mild winters. The natural vegetation is that of the transition between semideciduous seasonal forest (Mata atlântica) and predominance of Cerrado neotropical savannah (Oliveira Filho and Fontes, 2000). 
The soil in the experimental site was classified as a Cambissolo Háplico Distrófico (Cambisol) according to the Brazilian classification system (Santos et al., 2018) and as a Dystrudept (Inceptisol) according to U.S. soil taxonomy classification system (Soil Survey Staff, 2014). Fig. 2A represents the soil profiles observed in a neighboring natural vegetation spot, reference of soil condition prior to conversion to coffee plantation. Although major soil horizons are clearly defined, the profile presents a uniform texture, clayey down to $0.85 \mathrm{~m}$. In fact, soil characterization included soil bulk density, macroporosity and particle size analysis by the pipette method (Teixeira et al., 2017), considering granulometric fractions classified according to Soil Survey Staff (2014), performed on samples taken during profile observations (Table 1).

The study area occupies $240 \mathrm{~m}^{2}(24 \times 10 \mathrm{~m})$, located in gently rolling relief, maximum $12 \%$ slope gradient and soil organic matter varying 9 to $23 \mathrm{~g} \mathrm{~kg}^{-1}$ in the surface and subsurface horizons, respectively (Barbosa et al., 2020). Previously this area was occupied by degraded pasture. On December $23^{\text {rd }}, 2015$ the experiment started when the area was prepared with a harrow, the coffee plantation was performed in contour rows, with $3.6 \mathrm{~m}$ inter-rows distance and $0.75 \mathrm{~m}$ between plants in the row. Each plot has $9.75 \mathrm{~m}$ wide per line and one row per experimental unit, with 13 plants of coffee cultivar (Coffea arabica L.) Catuaí Vermelho - IAC 99.

\subsection{Experimental design}

This study was conducted within a more complex experimental area, completely described in Barbosa et al. (2020). Our experiment derived from this larger area was designed as randomized complete blocks with three replicates.

Treatments under test included soil preparation in the future coffee plant rows, based on furrowing down to different depths, in order to assess the effects of this profile mechanical disturbance on soil physical properties related to soil water availability for coffee plants. The effects on these properties of a deep rooting grass planted in the inter-row lanes of the coffee plantation were also assessed in the experiment, in order to compare biologically-based with mechanically-based improvements in naturally dense soil profiles assigned to coffee production, as it is the case of this study soil, according to Barbosa et al. (2020). The use of grass in the inter-row lanes is a conservationist practice already adopted by farmer. As so, it was considered an integral part of the planting system under study, namely on its influence on soil physical properties changes induced by mechanical soil preparation operations. As these were until very recently pristine Inceptisols, now being converted to farmland, the reference condition was found in the neighboring natural vegetation, labelled as Cerrado rupestrian vegetation.

Three different furrow depths in the future coffee plant rows, with furrows prepared to depths of $0.4 \mathrm{~m}, 0.6 \mathrm{~m}$ and $0.8 \mathrm{~m}$, are referred to as, respectively, treatments FP40, FP60 and FP80 throughout the text (Fig. 2C, D and E, respectively). The lanes between coffee plant rows were managed with Brachiaria-grass [Urochloa decumbens (syn. Brachiaria)], and this inter-row area is the treatment referred to as IR throughout the text (Fig. 2B). Brachiaria sowing was made by haul in October 2015, spreading $10 \mathrm{~kg} \mathrm{ha}^{-1}$ of seeds in a $2.5 \mathrm{~m}$ belt between the rows of coffee tree, keeping a distance of $1 \mathrm{~m}$ from these. Before flowering, the Brachiaria-grass was mechanically mowed to avoid competition with the coffee tree.



Fig. 1. Location of the experimental site in the municipality of Nazareno in Minas Gerais state, southeastern Brazil. 




C
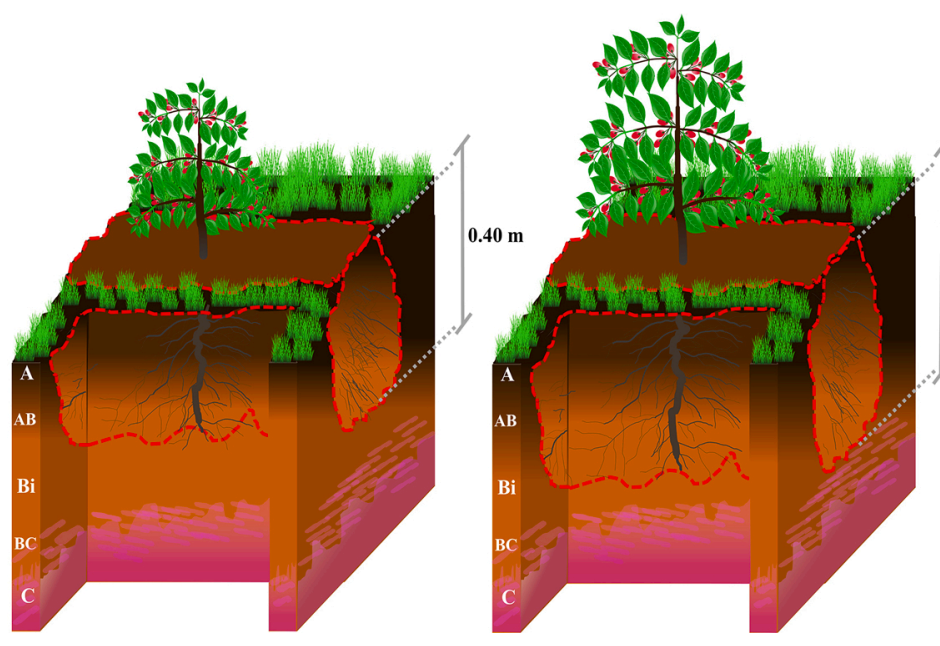

D

\section{Sample grid ---Planting furrow}
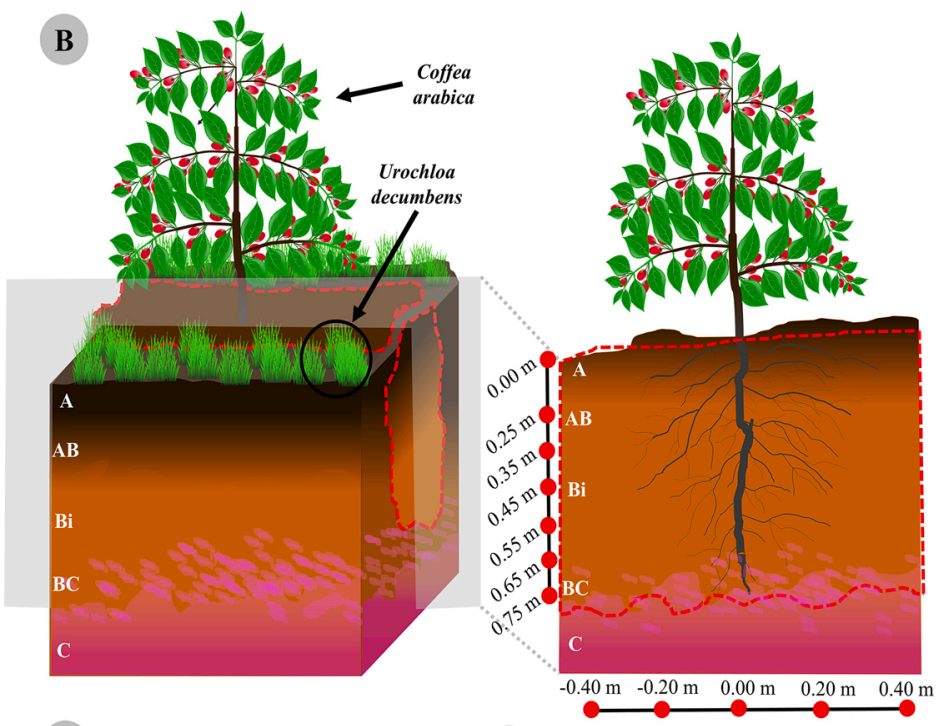

E



Fig. 2. Schematic representation of the Inceptisol profile under natural Cerrado vegetation (A), representation of the established sampling grid, in which sampling was performed longitudinally from the planting line (B), and cross-sectional view of the furrow preparation:FP40 = furrowing preparation to a depth of $0.40 \mathrm{~m}$ (C); FP60 = furrow preparation to a depth of $0.60 \mathrm{~m}(\mathrm{D})$; FP80 = furrow preparation to a depth of $0.80 \mathrm{~m}(\mathrm{E}) . \mathrm{A}, \mathrm{AB}, \mathrm{Bi}, \mathrm{BC}$ and C are soil horizons.

Table 1

Bulk density, macroporosity and textural analysis of the experimental site Inceptisol (Campos das Vertentes physiographic zone, Minas Gerais state, Brazil): soil reference condition prior to coffee plantation.

\begin{tabular}{|c|c|c|c|c|c|c|c|c|c|c|}
\hline \multirow{2}{*}{ Horizon } & \multirow{2}{*}{ Layer (m) } & \multirow{2}{*}{$\begin{array}{l}\mathrm{Bd} \\
\left(\mathrm{Mg} \mathrm{m}^{-3}\right)\end{array}$} & \multirow{2}{*}{$\begin{array}{l}\text { Macro } \\
\left(\mathrm{m}^{3} \mathrm{~m}^{-3}\right)\end{array}$} & \multicolumn{7}{|c|}{ Granulometric fractions $\left(\mathrm{g} \mathrm{kg}^{-1}\right)$} \\
\hline & & & & VCS & $\mathrm{CS}$ & MS & FS & VFS & Silt & Clay \\
\hline A & $0.00-0.08$ & 1.09 & 0.19 & 32 & 46 & 101 & 159 & 43 & 142 & 477 \\
\hline $\mathrm{AB}$ & $0.08-0.33$ & 1.37 & 0.09 & 28 & 44 & 94 & 136 & 46 & 174 & 478 \\
\hline $\mathrm{Bi}$ & $0.33-0.65$ & 1.25 & 0.11 & 29 & 36 & 115 & 155 & 45 & 141 & 479 \\
\hline BC & $0.65-0.85$ & 1.07 & 0.15 & 33 & 41 & 85 & 149 & 46 & 185 & 461 \\
\hline
\end{tabular}

Horizons classified according to the methods of Santos et al. (2018). Bd: Bulk density; Macro: macroporosity (equivalent pore diameter $>0.05 \mathrm{~mm}$ ); Granulometric fractions: VCS = very coarse sand $(2.00-1.00 \mathrm{~mm}) ; \mathrm{CS}=$ coarse sand $(1.00-0.50 \mathrm{~mm}) ; \mathrm{MS}=$ medium sand $(0.50-0.25 \mathrm{~mm}) ; \mathrm{FS}=$ fine sand $(0.25-0.10 \mathrm{~mm})$; VFS = very fine sand $(0.10-0.05 \mathrm{~mm})$, silt $(0.05-0.002 \mathrm{~mm})$; clay $(<0.002 \mathrm{~mm})$.

A nearby natural spot of Cerrado (a rupestrian field), whose topographical and edaphic conditions were similar to those of the experimental site; was taken as reference treatment (NC). In this spot, sampling was performed at least $15 \mathrm{~m}$ away from the coffee plantation field to avoid boundary effects (Figs. 1 and 2A).

\subsection{Treatments implementation}

The operations performed before coffee planting are listed in Table 2 for the different treatments tested. In the furrowing treatments (FP40, FP60 and FP80). The furrows were created by a furrow ridger (working depth of $0.4 \mathrm{~m}$ ) in the FP40 treatment, while in the other treatments, 
subsoilers was used for preparing the soil to depths off 0.6 (soil preparer) and $0.8 \mathrm{~m}$ (subsoiler dreno), FP60 and FP80, respectively. For both FP60 and FP80, the furrowed soil was then thoroughly mixed by a soil preparer (Big Mix AS-2, Mafes Agromecânica) with a working depth of 0.6 $\mathrm{m}$.

Throughout the entire experimental site, before applying the treatments, tillage was performed with a heavy harrow ( $2.25 \mathrm{~m}$ wide, with 18 disks of $0.66 \mathrm{~m}$ diameter) coupled to a tractor (power of $111.86 \mathrm{~kW}$ ).

\subsection{Sampling scheme}

Soil sampling was performed equally in the experimental plots in two

Table 2

Summary of the operations conducted in the present study, in each treatment of the experimental area.

\begin{tabular}{lllllll}
\hline \multirow{2}{*}{ Operations } & \multicolumn{3}{l}{ Treatments } & & \\
\cline { 2 - 6 } & NC & IR & FP40 & FP60 & FP80 \\
\hline Harrowing $0.20 \mathrm{~m} \mathrm{deep}^{(1)}$ & $\mathbf{x}$ & $\checkmark$ & $\checkmark$ & $\checkmark$ & $\checkmark$
\end{tabular}

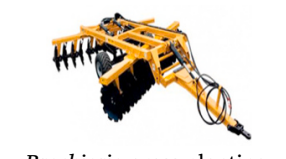

Brachiaria-grass planting



furrow ridger ${ }^{(2)}$

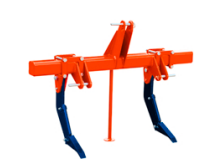

Soil preparer to $0.60 \mathrm{~m}$ deep (mixing soil in the planting furrow down to $0.60 \mathrm{~m}$ depth) ${ }^{(3)}$

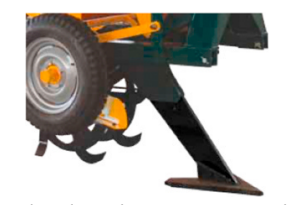

Subsoiling down to $0.80 \mathrm{~m}$ deep ${ }^{(4)}$


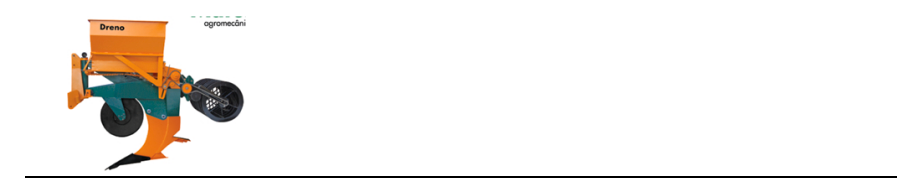

Treatments: NC = natural Cerrado vegetation; IR = inter-rows of coffee plants intercropped with Brachiaria-grass; FP40 = furrowing to a depth of $0.40 \mathrm{~m}$; FP60 $=$ furrowing and mixing to a depth of $0.60 \mathrm{~m}$; FP80 = furrowing to a depth of $0.80 \mathrm{~m}$ and mixing to a depth of $0.60 \mathrm{~m}$;

(1) harrow Santa Izabel GASI 360, São João da Boa Vista, São Paulo Brazil.

(2) trencher Kamaq C107B2, Mogi das Cruzes, São Paulo, Brazil.

(3) soil preparer Big Mix Mafes Agromecânica, Mogi das Cruzes, São Paulo, Brazil.

(4) subsolier furrows Dreno Mafes Agromecânica, Mogi das Cruzes, São Paulo, Brazil. evaluation positions: (i) where furrowing treatments were applied (each 3 blocks), and; (ii) in IR treatment. Natural Cerrado vegetation spot (NC) was included in the sampling design to represent the reference soil physical condition in the absence of anthropic intervention and its influence in porosity and hydraulic properties changes along the soil profile ( 3 randomized points). A total of 15 profiles (sampling grid with dimensions: $0.75 \mathrm{~m} \times 0.80 \mathrm{~m}$ ) were exposed and soil sampling took place 18 months after the establishment of the experiment, in May 2017. After pits excavation, 105 undisturbed soil samples (5 treatments $\mathrm{x} 7$ layers $\mathrm{x}$ 3 replicates) were collected in the direction of the cultivation line (Fig. 2B), for saturated hydraulic conductivity, and the same number for soil water retention curve laboratory determination. Pore size distribution and unsaturated hydraulic conductivity were derived from those lab determinations.

All these parameters describe the soil porosity status and the related soil water dynamics, in saturated and unsaturated conditions, for the entire soil profile affected by treatments applied. Additionally, infiltration tests under different suction heads were performed in order to have a further insight on the actual field behavior of surface soil of treatments applied in the experimental site. This was judged an essential additional information considering field observations during sampling runs, as surface crusts (0-0.005 m layer) were visible either in the rupestrian field (NC) or in the other treatments. To support the interpretation of field observations, these layers were sampled in all experimental plots and analyzed for particle size distribution, samples being collected on a $0.5 \times 0.5 \mathrm{~m}$ square placed onto the surface in areas depicting such features.

Field, laboratory and calculation procedures applied for determining the above soil parameters are described in the following subsections.

\subsection{Water infiltration}

The final infiltration rate (FIR) was determined (each block) in the rows planted with coffee in FP40, FP60 and FP80 and 3 randomly points in the IR and NC treatments using a tension-disk infiltrometer (Soil Measurement Systems, Tucson, USA) with a basal diameter of $0.25 \mathrm{~m}$ (Perroux and White, 1988). Measurements were made under water potentials of $0,-0.05,-0.20$ and $-0.30 \mathrm{~m}$, allowing assessment water intake rates under both saturated (water potential equal to zero, with water filling all of the soil pores) and unsaturated conditions (negative water potential). The infiltrometer was placed at the soil surface and regulated to the desired water potential (Perroux and White, 1988). Measurements were taken until a steady flow rate was achieved. The FIR was calculated by the following Eq. 1:

$F I R=q * 60\left(\frac{D t^{2}}{D b^{2}}\right)$

in which the FIR is the final infiltration rate $\left(\mathrm{mm} \mathrm{h}^{-1}\right), \mathrm{q}$ is the steady flow rate of the tension infiltrometer $\left(\mathrm{mm} \mathrm{min}^{-1}\right), D t$ is the diameter of the infiltrometer tube ( $\mathrm{mm}$ ), and $D b$ is the basal diameter of the tension infiltrometer $(\mathrm{mm})$.

\subsection{Saturated hydraulic conductivity $\left(K_{0}\right)$}

The soil saturated hydraulic conductivity $\left(K_{0}\right)$ was determined in undisturbed samples collected with an Uhland sampler in metallic cylinders ( $0.064 \mathrm{~m}$ wide and $0.08 \mathrm{~m}$ high). During each sampling run, five samples were collected along the sampling grid (Fig. 2B) in the rows planted with coffee in FP40, FP60 and FP80, and randomly in the IR and NC treatments, summing 35 undisturbed samples for each treatment.

In the laboratory, samples were moistened by capillarity until complete saturation ( $24 \mathrm{~h}$ average) prior to the permeability test. This was conducted in a constant-head permeameter (Klute, 1965). The apparatus was upgraded with a collector installed in the sample-holding socket, specially designed to prevent the collection of water flowing 
preferentially on the cylinder inner walls (Lima et al., 1990). The saturated hydraulic conductivity was calculated according to the Darcy-Willians model (Eq. 2) (Klute, 1965) as follows:

$K_{0}=\frac{V_{A} L}{A t\left(H_{\text {c.water }}+L\right)}$

in which $K_{0}$ is the soil saturated hydraulic conductivity $\left(\mathrm{mm} \mathrm{h}^{-1}\right), V_{A}$ is the volume of water collected during a certain time $\left(\mathrm{mm}^{3}\right)$ considering the flow value after three constant readings, $A$ is the cross-sectional area of the water collector $\left(\mathrm{mm}^{2}\right), L$ is the height of the cylinder (mm), $H_{c}$. water is the height of the water column on top of the soil sample (mm), and $t$ is the time (hours). $K_{0}$ was determined from the average of 3 readings, according to Klute's (1965) guidelines.

\subsection{Soil water retention curve}

To obtain water retention curves (WRC), undisturbed samples were collected in metallic cylinders ( $0.064 \mathrm{~m}$ diameter, $0.025 \mathrm{~m}$ height) using an Uhland sampler in rows planted with coffee in FP40, FP60 and FP80, and randomly in the IR and NC treatments. In the laboratory, samples were saturated by capillary with distilled water and were subjected to eight total matric potentials: saturated soil water content (adopted as $0 \mathrm{kPa}$ ); $-2,-4,-6$ and $-10 \mathrm{kPa}$ in porous-plate funnels; and $-33,-100,-500$ and $-1500 \mathrm{kPa}$ in porous-plate extractors (Teixeira et al., 2017). After reaching hydraulic equilibrium (no drainage outflow), samples were weighed. Following the last matric potential, the samples were oven dried $\left(105^{\circ} \mathrm{C}\right.$ for $\left.24 \mathrm{~h}\right)$ to determine the volumetric water content $(\theta)$ at each of the potentials, considering, the ratio between volume of water and the total volume of the sample. The water content was related to the matric potential by fitting the data to the model proposed by van Genuchten (1980) (Eq. 3):

$\theta=\left(\theta_{s}-\theta_{r}\right)\left[1+(\alpha h)^{n}\right]^{-m}+\theta_{r}$

where $\theta$ is the soil water content $\left(\mathrm{m}^{3} \mathrm{~m}^{-3}\right)$; $\theta_{S}$ is the saturated soil water content $\left(\mathrm{m}^{3} \mathrm{~m}^{-3}\right)$, measured after soil sample saturation; $\theta_{R}$ was assumed as the soil water content at a $-1500 \mathrm{kPa}$ matric potential $\left(\mathrm{m}^{3}\right.$ $\left.\mathrm{m}^{-3}\right) ; h$ is the soil water tension $(\mathrm{kPa})$; and $\alpha, n$ and $m=(1-1 / n)$ are fitted empirical parameters.

\subsection{Pore size distribution}

The normalized pore size distribution, $S(h)$, was calculated from the first derivative of Eq. 4 according to the methods of Reynolds et al. (2009), where first, the pore volume distribution function, $S_{v}(h)$, was defined as the slope of the WRC expressed in a graph showing the volumetric water content, $\theta\left(\mathrm{m}^{3} \mathrm{~m}^{-3}\right)$, versus $\ln (h)$ :

$S_{v}(h)=m(\alpha h)^{n}\left[1+\frac{1}{m}\right]^{(m+1)}$

The pore size distribution was graphically represented as a frequency distribution curve of the equivalent pore diameter (d) on a log10 scale. Reynolds et al. (2009) define the normalized pore volume distribution function, $\mathrm{S}(\mathrm{h})$, dividing $\mathrm{S}_{\mathrm{v}}(h)$ by $\mathrm{S}_{\mathrm{vi}}$, resulting in Eq. 5:

$S(h)=\frac{S_{v}(h)}{S_{v i}}=\frac{m(\alpha h)^{n}\left[1+m^{-1}\right]^{m+1}}{\left[1+(\alpha h)^{n}\right]^{(m+1)}} ; 0 \leq S(h) \leq 1$

in which $\mathrm{S}_{\mathrm{vi}}$ is the peak of the pore volume distribution, corresponding to the slope of the inflection point of the WRC according to Dexter (2004).

The pore size distribution was based on the mathematical expression by Bouma (1991) and categorized according to criteria derived from soil micromorphology (Carducci et al., 2015), with the pores divided into macropores $(>73 \mu \mathrm{m})$; large mesopores $(73-29 \mu \mathrm{m})$; medium mesopores $(29-2.9 \mu \mathrm{m})$; fine mesopores $(2.9-0.2 \mu \mathrm{m})$; and micropores $(<$
$0.2 \mu \mathrm{m})$ Eq. 6:

$D=4 \sigma \operatorname{Cos} \theta / \psi_{m}$

where $\mathrm{D}$ is the pore diameter $(\mathrm{mm}) ; \sigma$ is the surface tension of water $\left(73.43 \mathrm{kPa} \mu \mathrm{m}\right.$ at $\left.20^{\circ} \mathrm{C}\right) ; \theta$ is the contact angle between the meniscus and the capillary tube wall (considered as 0 ); and $\psi_{\mathrm{m}}$ is the water tension in the soil $(\mathrm{kPa})$.

\subsection{Unsaturated hydraulic conductivity}

The unsaturated hydraulic conductivity $(K)$ was calculated according to the model proposed by van Genuchten (1980), in which $K$ is determined by the product of $K_{0}$ (Eq. 2) and the relative hydraulic conductivity $\left(K r, \mathrm{~mm} \mathrm{~h}^{-1}\right)$ given in Eqs. 7 and 8 with the restriction of $\mathrm{m}=1$ (1/n) (Mualem, 1976).

$K_{r}(h)=\frac{\left\{-(\alpha h)^{n-1}\left[1+(\alpha h)^{n}\right]^{-m}\right\}^{2}}{\left[1+(\alpha h)^{n}\right]^{\frac{m}{2}}}$

$K=K_{r}(h) K_{0}$

\subsection{Statistical analysis}

Geostatistical methods were applied to the $K_{0}$ data obtained according to the sampling grid represented in Fig. $2 \mathrm{~B}$. $K_{0}$ grouped data standard deviation (SD) and coefficient of variation (CV) were also calculated (Table 3). These methods included a spatial exploratory analysis of the data, boxplot graphs to identify possible outliers, and postplot graphs to identify directional tendency in the data. Isotropy was evaluated by constructing directional semivariograms at $0,45,90$ and $135^{\circ}$ (Guedes et al., 2008), $0^{\circ}$ being the coffee plantation row.

The spatial variability of $K_{0}$ was assessed by the semivariance estimated according to the estimator of Matheron (Cressie, 1993) for a geographically located variable $Z\left(S_{i}\right)$ with Gaussian distribution, according to Eq. 9:

$\gamma(h)=\frac{1}{2 N(d)} \sum_{i=1}^{N(d)}\left[z\left(S_{i}\right)-z\left(S_{i}+d\right)\right]^{2}$

in which $Z\left(S_{i}\right)$ and $Z\left(S_{i}+d\right)$ are the values of the regionalized variable at the positions $S_{i}$ and $S_{i}+d$, with $S_{i}$ being a spatial coordinate ( $x i, y i$ ) and $S$ being a parametric space of $\mathrm{R}^{2} ; N(d)$ corresponds to the number of data points separated by the distance $d$.

The choice of the spherical model (Eq. 10) was based on the following criteria: lower AIC (Akaike information criterion) and SEM (standard error about the mean), higher $\mathrm{R}^{2}$ (see Tables $1,2,3,4$, and table 5 in supplementary material). Subsequently the model was fitted to the experimental semivariograms (Cressie, 1993; Diggle and Ribeiro Junior, 2007; Coelho et al., 2009) as follows:

Table 3

Statistics of the global soil profile saturated hydraulic conductivity $\left(\mathrm{mm} \mathrm{h}^{-1}\right)$ in each treatment tested in the experimental site.

\begin{tabular}{llllll}
\hline Statistics & NC & IR & FP40 & FP60 & FP80 \\
\hline Number of samples $^{(1)}$ & 105 & 105 & 105 & 105 & 105 \\
Mean & 30.71 & 40.99 & 29.73 & 61.61 & 102.02 \\
Standard deviation & 20.27 & 42.61 & 41.86 & 71.12 & 100.83 \\
Coefficient of variation (\%) & 66.01 & 103.96 & 140.78 & 115.43 & 98.87 \\
\hline
\end{tabular}

(1) Means of the repetitions in each treatment. Treatments: NC = natural Cerrado vegetation; IR = inter-rows of coffee plants intercropped with $\mathrm{Bra}$ chiaria-grass; FP40 = furrowing to a depth of $0.40 \mathrm{~m}$; FP60 = furrowing and mixing to a depth of $0.60 \mathrm{~m}$; FP80 = furrowing to a depth of $0.80 \mathrm{~m}$ and mixing to a depth of $0.60 \mathrm{~m}$. 
$\gamma(d)=C_{0}+C_{1}\left[\frac{3}{2}\left(\frac{d}{a}\right)-\frac{1}{2}\left(\frac{d}{a}\right)^{3}\right] ; 0<d<a$

in which $C_{0}$ is the nugget effect, $C_{1}$ is the sill, $d$ is the distance between pairs of points, $a$ is the range, and $\mathrm{d}$ is the maximum distance for which the semivariogram is defined. To assess the efficiency of the fitted model, the spatial dependency $(S D, \%)$ was calculated according to the proposed method of Cambardella et al. (1994) (Eq. 11).

$\mathrm{SD}=\left(\frac{\mathrm{C}_{1}}{\mathrm{C}_{0}+\mathrm{C}_{1}}\right) 100$

in which a smaller SD indicates a model with a better structure of spatial continuity. Also, according to the same authors, SD can be classified into three categories: strong ( $\mathrm{SD}<25 \%$ ), moderate $(26 \%<\mathrm{SD}<$ $75 \%$ ), and weak spatial dependence (SD > $75 \%$ ).

The model parameters of the fitted semivariograms were then used to estimate $K_{0}$ in unsampled locations through ordinary kriging. $K_{0}$ values in the maps obtained were classified according to Beutler et al. (2001): $K_{0}>254 \mathrm{~mm} \mathrm{~h}^{-1}$ for high, 254-127 for moderate to high, 127-63.5 for moderate, $63.5-20$ for low to moderate, $20-5$ for low and $<5$ for very low.

Analysis of variance was applied for the infiltration data, and the means were compared via the Skott-Knott test $(p \leq 0.05)$ (Borges and Ferreira, 2002).

The model parameters of the soil water retention curve (which were used to determine the pore size distribution and the unsaturated hydraulic conductivity) were estimated by the nonlinear least-squares method (Ritz and Streibig, 2008).

The statistical tests, graphs and thematic maps were all constructed with software R 3.4.1 (R Core Team, 2017) and the packages geoR (Ribeiro Junior and Diggle, 2001) and ggplot2 (Wickham, 2009).

\section{Results}

The results of particle size analyses of surface crusts observed in the natural Cerrado of the rupestrian field (NC) and in the $0.0-0.005 \mathrm{~m}$ layer in the coffee plantation are shown in Fig. 3. No significant differences were found in Clay, VFS, CS, and VCS contents by ANOVA, when comparing treatments and reference. Particle size classes of soil top layer most affected by treatments were the Silt and MS, with contents significantly lower and higher than found in reference (NC), respectively, while for FS, only the deeper furrowing treatments (F60 and F80) showed significantly higher contents than NC.

The FIR values for the different treatments including the reference, the Cerrado vegetation (NC), are describe in Fig. 4. As compared to NC, treatments significantly affected the infiltrometer readings under water potentials of $0.0,-0.05$ and $-0.20 \mathrm{~m}$. At the $0.0 \mathrm{~m}$ water potential (which represents the infiltration of saturated soil condition), the FIR increased on average by $146 \%, 206 \%, 213 \%$ and $188 \%$ for the FP40, FP 60 , FP80 and IR treatments, respectively, in comparison to NC. Under $-0.05 \mathrm{~m}$ water potential, FIR for FP60 and FP80 was almost four times higher than that in NC (396 \% and $388 \%$ higher, respectively).

Saturated hydraulic conductivity $\left(K_{0}\right)$ presented high variability in the soil profiles in the different treatments, as reflected by the coefficient of variation values, ranging from 66.01 in the natural Cerrado vegetation to $140.78 \%$ in furrow prepared to a depth of $0.40 \mathrm{~m}$ (Table 3 ), which is common for this soil parameter. It is important to note that the $K_{0}$ laboratory-derived values (up to $0.80 \mathrm{~m}$ - Fig. 6) were lower than in the field (evaluation carried out at the surface - Fig. 4) but also reveal the different behavior of the soil water regime between treatments.

The experimental semivariance of the residuals for $K_{O}\left[\left(\mathrm{~mm} \mathrm{~h}^{-1}\right)^{2}\right]$ presented spatial dependence that fit the spherical model well (Fig. 5), compared to other empirical models (supplementary material), and the kriging maps (Fig. 6) indicate higher $K_{0}$ values (fast and moderately fast) in FP60 (to a depth of $0.25 \mathrm{~m}$ ) and FP80 (to a depth of $0.43 \mathrm{~m}$ ) than in the other treatments (FP40, IR and NC).

The fitted parameters for soil water retention curves with the respect coefficients of determination are showed in Table 4 and soil water retention curves, pore size distribution curves and unsaturated hydraulic conductivity curves in Fig. 7. There are large volumes of macropores $(>73 \mu \mathrm{m})$, large mesopores $(29-73 \mu \mathrm{m})$ and medium mesopores $(2.9-29 \mu \mathrm{m})$ for the FP60 and FP80 treatments in the $0.00-0.40 \mathrm{~m}$ soil layers in comparison with those of the other treatments (FP40, IR and NC).

\section{Discussion}

\subsection{Soil texture of surface crusting}

Changes in particle size distribution in the surface layer as compared to reference (NC) may result from mixing soil layers during plantation operations in treatments but, with a fairly uniform granulometric profile this effect was seemingly not dominant in the experimental area. Changes may also result from splash, disrupting surface structure, and selective particles wash by runoff (Poesen, 1985; Valentin and Bresson, 1992), seemingly a more important effect than soil layers mixture. Indeed, as compared to the reference (NC), with the limited growth and sparse vegetation, Brazilian rupestrian fields (Mucina, 2018) treatments have a higher vegetation cover (coffee and Brachiaria), therefore intercepting raindrops, limiting splash and runoff generation. As well, in the

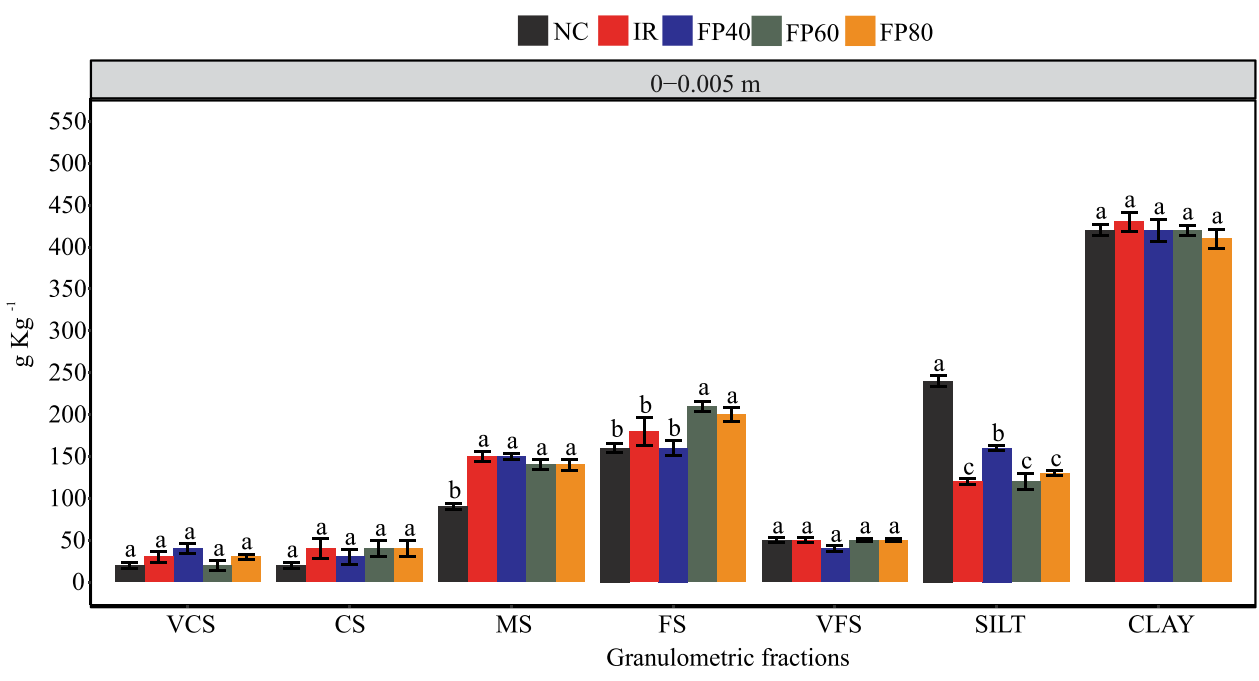

Fig. 3. Soil texture of surface crusts in the 0.0$0.005 \mathrm{~m}$ layer of an Inceptisol from a rupestrian field of natural Cerrado (NC) and from interrows of coffee plants intercropped with $\mathrm{Bra}$ chiaria-grass (IR) and subjected to the following treatments: FP40, furrowing to a depth of 0.4 m; FP60, furrowing and mixing to a depth of $0.60 \mathrm{~m}$; and FP80, furrowing to a depth of 0.80 $\mathrm{m}$ and mixing to a depth of $0.60 \mathrm{~m}$. Granulometric fractions: VCS = very coarse sand (2.00$1.00 \mathrm{~mm})$; $\mathrm{CS}=$ coarse sand $(1.00-0.50 \mathrm{~mm})$; $\mathrm{MS}=$ medium sand $(0.50-0.25 \mathrm{~mm}) ; \mathrm{FS}=$ fine sand $(0.25-0.10 \mathrm{~mm})$; VFS $=$ very fine sand (0.10-0.05 mm); silt (0.05-0.002 mm); clay (< $0.002 \mathrm{~mm}$ ). The means followed by the same letter are not significantly different according to the Skott-Knott test ( $\mathrm{p} \leq 0.05$ ). 


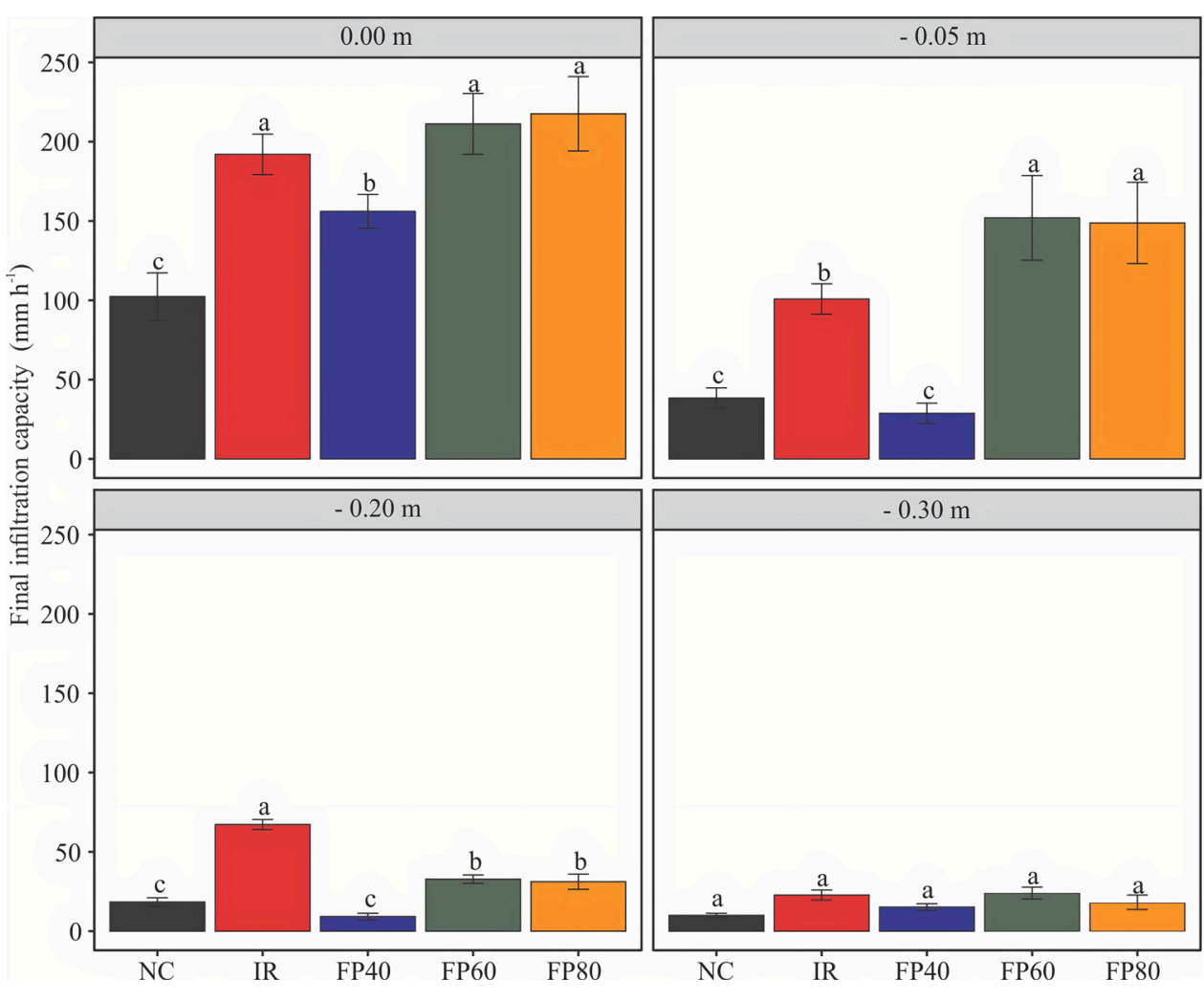

Fig. 4. Final infiltration rate under water potentials of $0.0,-0.05,-0.20$ and $-0.30 \mathrm{~m}$ in an Inceptisol under natural Cerrado vegetation (NC) and inter-rows of coffee plants intercropped with Brachiaria-grass (IR). The coffee plants were managed according to the following systems: FP40, furrowing to a depth of $0.4 \mathrm{~m}$; FP60, furrowing and mixing to a depth of 0.60 $\mathrm{m}$; and FP80, furrowing to a depth of $0.80 \mathrm{~m}$ and mixing to a depth of $0.60 \mathrm{~m}$. The means followed by the same letter are not significantly different according to the Skott-Knott test ( $\mathrm{p} \leq$ 0.05).

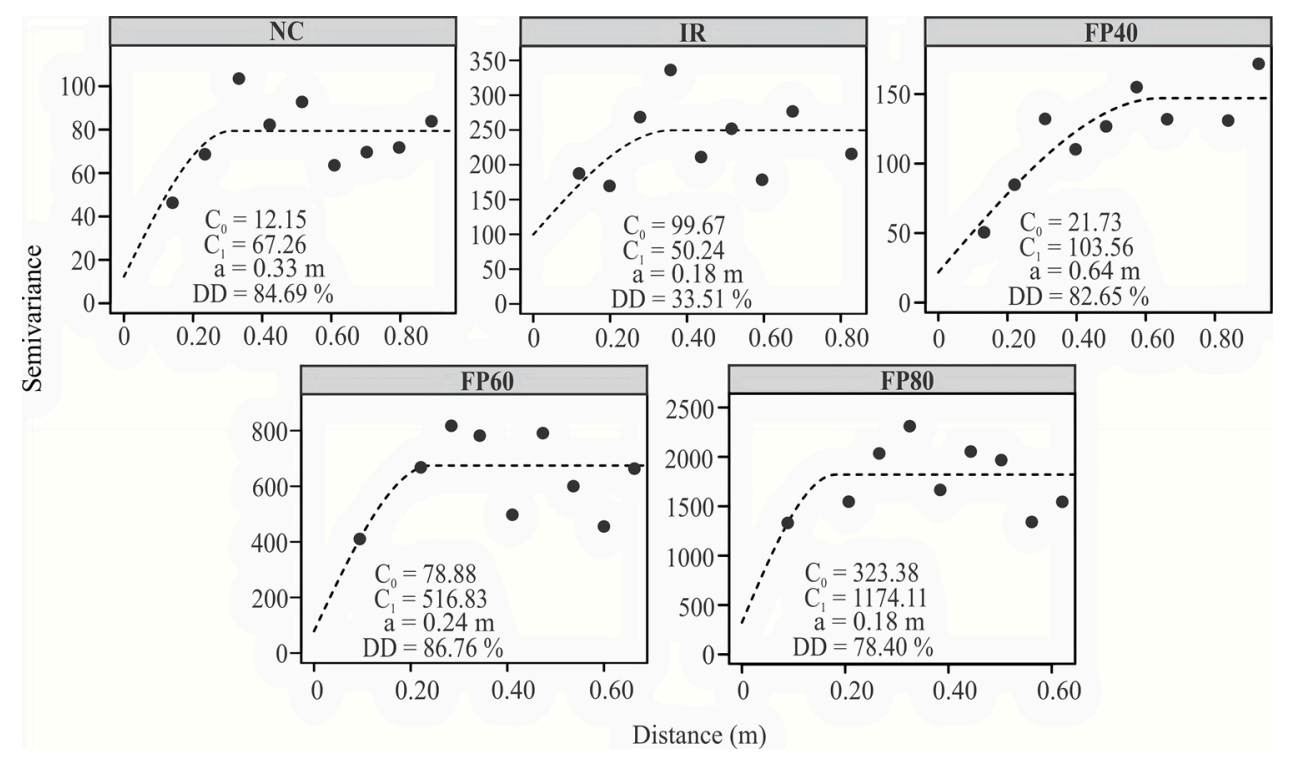

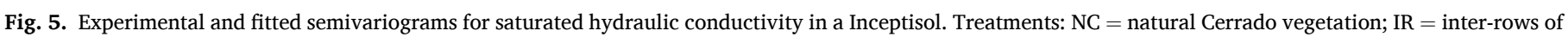

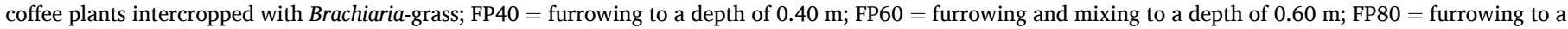
depth of $0.80 \mathrm{~m}$ and mixing to a depth of $0.60 \mathrm{~m}$. Semivariogram parameters: $\mathrm{C}_{0}=$ nugget; $\mathrm{C}_{1}=$ sill; $\mathrm{a}=$ range; $\mathrm{SD}=\mathrm{degree}$ of spatial dependence.

reference (NC), selective runoff wash seemingly persisted through time so as to form silt enriched crusts, as Silt content in NC crusts is higher than that of the soil "A" horizon prior to coffee plantation (Fig. 3 and Table 1).

Field observations confirmed that deep furrowing or the inter-row cover by Brachiaria-grass, limited visible surface crust formation 18 months after coffee plantation. It is noteworthy that this period is the most critical for accelerated crusting, as it corresponds to maximum disturbance due to soil preparation for a perennial crop establishment, the soil not being mechanically disturbed again for at least 10-15 years in the case of coffee in this region. Crusting is common in soils of Campos das Vertentes physiographic region in Minas Gerais state, Brazil, especially in Inceptisols, generally characterized by low water infiltration capacity. Besides crusting, these soils are shallow effective depth, weakly developed structure and naturally dense (Santos et al., 2018; Soil Survey Staff, 2014); thus, all factors combined, they are highly susceptible to runoff generation during rainfalls that represents a water loss for the cropping system (Silva et al., 2005), largely affecting the soil water regime.

The increase in content of silt-size particles are a major element of 


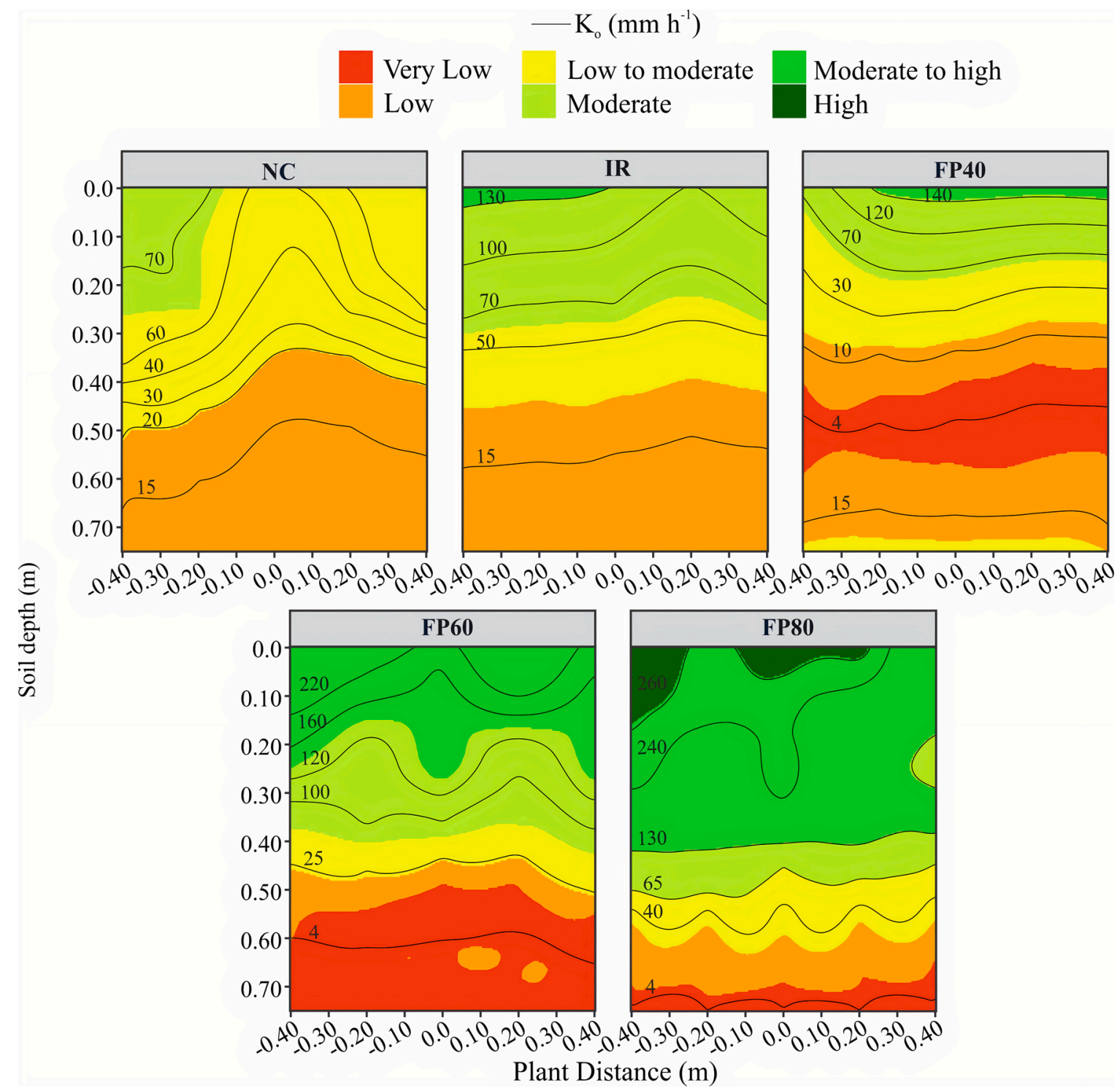

Fig. 6. Soil profile permeability maps $\left(K_{0}, \mathrm{~mm} \mathrm{~h}^{-1}\right)$ in an Inceptisol. Treatments: $\mathrm{NC}=$ natural Cerrado vegetation; IR = inter-rows of coffee plants intercropped with Brachiaria-grass; FP40 = furrowing to a depth of $0.40 \mathrm{~m}$; FP60 = furrowing and mixing to a depth of $0.60 \mathrm{~m}$; FP80 = furrowing to a depth of $0.80 \mathrm{~m}$ and mixing to a depth of $0.60 \mathrm{~m}$.

surface crusts (Le Bissonnais and Bruand, 1993; Figueiredo and Poesen, 1998; Kuhn et al., 2012). It was observed that, as compared with FP40, the FP60 and FP80 treatments showed a considerable lower silt content, halving that found in NC. Besides the sparse cover provided by natural vegetation in $\mathrm{NC}$, thus weakly protecting the soil against raindrops impact, recurrent fires are common in the region, affecting Cerrado vegetation. Surface heating causes organic matter volatilization and condensation, which may generate a hydrophobic layer limiting infiltration and promoting runoff (Fox et al., 2007; Madsen et al., 2011). On the contrary, deep soil preparation techniques, as those tested in the experiment, significantly reduced surface silt content, decreasing the natural susceptibility of Inceptisols to crusting. The dense vegetation cover provided by IR in the coffee inter-row lanes gave similar results, meaning that combining deep soil preparation in coffee plant rows with intercropped Brachiaria leads to a reduction in silt-size content when compared to that found in NC (Fig. 3) that leads to a reduction in susceptibility to crusting in the entire plot area.

It is worthy to stress that the content of Silt plus VFS directly relates to soil erodibility (K-USLE), whose calculated value is $0.057 \mathrm{Mg}$ ha $\mathrm{h}$ $\mathrm{ha}^{-1} \mathrm{MJ}^{-1} \mathrm{~mm}^{-1}$ (nomogram by Wischmeier and Smith, 1978), which is considered high. As compared to NC, treatments tested all induced lower silt contents in uppermost soil layer, which means reducing soil erodibility, considering that treatments effect in VFS was not statistically significant. This is especially the case of IR, FP60 and FP80, where better control of soil and water losses by runoff erosion may be achieved not only because these treatments provided more effective vegetation cover but also because they lowered the intrinsic susceptibility of soils to erosion.

Together with water, soil conservation is an important issue that has to be accounted for when testing soil preparation for coffee plantation in the study area, especially considering its high susceptibility to rainfall erosion. Santos et al. (1998) measured soil losses of $151 \mathrm{Mg} \mathrm{ha}^{-1}$ year $^{-1}$ in Cambisols on standard erosion plots in this same study region, while Silva et al. (2005), also on standard erosion plots, measured soil losses higher than $200 \mathrm{Mg} \mathrm{ha}^{-1}$ and water losses approximately $30 \%$ of total rainfall in pasture plots, similar to the NC area sampled in this study. These important observed soil and water losses by runoff erosion in both studies cited were attributed to surface crusting and are well above the tolerance for soils in tropical climates. The conversion of such areas into coffee plantations following soil preparation and management practices 
Table 4

Fitted parameters for soil water retention curves (van Genuchten, 1980) at different layers of an Inceptisol subjected to different treatments.

\begin{tabular}{|c|c|c|c|c|c|}
\hline Treatments & NC & IR & PS40 & PS60 & PS80 \\
\hline & & $0.00-0.05 \mathrm{~m}$ & & & \\
\hline$\theta_{R}$ & $0.212 *$ & $0.209 * *$ & $0.247 * *$ & $0.262 * * *$ & $0.270 *$ \\
\hline$\theta_{S}$ & $0.577 *$ & $0.620 * *$ & $0.640 *$ & $0.653 * *$ & $0.660 *$ \\
\hline$\alpha$ & $0.921 * *$ & $0.678 * * *$ & $0.636 *$ & $0.592 * * *$ & $0.504 * *$ \\
\hline$n$ & $1.556 * *$ & $1.546 * *$ & $1.497 * * *$ & $1.412^{\mathrm{ns}}$ & $1.457 * *$ \\
\hline $\mathrm{R}^{2}$ & 0.993 & 0.996 & 0.991 & 0.990 & 0.993 \\
\hline \multicolumn{6}{|l|}{$0.25-0.30 \mathrm{~m}$} \\
\hline$\theta_{R}$ & $0.241 * *$ & $0.243 * *$ & $0.240 * *$ & $0.269 * * *$ & $0.285 * * *$ \\
\hline$\theta_{S}$ & $0.568^{\mathrm{ns}}$ & $0.577 * *$ & $0.555 * *$ & $0.616 * * *$ & $0.633^{\mathrm{ns}}$ \\
\hline$\alpha$ & $0.325 * *$ & $0.356 *$ & $0.776 * * *$ & $0.507 * *$ & $0.540 * *$ \\
\hline$n$ & $1.849 *$ & $1.804 * * *$ & $1.577 *$ & $1.547 * *$ & $1.523 *$ \\
\hline $\mathrm{R}^{2}$ & 0.991 & 0.996 & 0.997 & 0.992 & 0.994 \\
\hline \multicolumn{6}{|c|}{$0.35-0.40 \mathrm{~m}$} \\
\hline$\theta_{R}$ & $0.243 * *$ & $0.237 * * *$ & $0.229 * *$ & $0.243^{\mathrm{ns}}$ & $0.247 *$ \\
\hline$\theta_{S}$ & $0.573 * * *$ & $0.561 * * *$ & $0.517 * * *$ & $0.609 *$ & $0.616 * * *$ \\
\hline$a$ & $0.740 * *$ & $0.901 * * *$ & $0.940 * *$ & $0.444 * * *$ & $0.633 * * *$ \\
\hline$\alpha$ & $1.633 * * *$ & $1.580 * * *$ & $1.638 * *$ & $1.586 * *$ & $1.470 * *$ \\
\hline $\mathrm{R}^{2}$ & 0.998 & 0.999 & 0.998 & 0.992 & 0.994 \\
\hline \multicolumn{6}{|c|}{$0.45-0.50 \mathrm{~m}$} \\
\hline$\theta r$ & $0.266 *$ & $0.257 * *$ & $0.258 * * *$ & 0.254 * & $0.282 * *$ \\
\hline$\theta_{S}$ & $0.580 * *$ & $0.573 * *$ & $0.495 * * *$ & $0.598 * *$ & $0.612 *$ \\
\hline$a$ & $0.623 *$ & $0.569 *$ & $0.513 * * *$ & $0.401 * *$ & $0.427 * *$ \\
\hline$\alpha$ & $1.470 *$ & $1.461 *$ & $1.645 * * *$ & $1.518 * *$ & $1.466 *$ \\
\hline $\mathrm{R}^{2}$ & 0.994 & 0.996 & 0.999 & 0.995 & 0.992 \\
\hline \multicolumn{6}{|c|}{$0.55-0.60 \mathrm{~m}$} \\
\hline$\theta_{R}$ & $0.288 * *$ & $0.290 * *$ & $0.268 * *$ & $0.267 * *$ & $0.279 *$ \\
\hline$\theta_{S}$ & $0.560^{\mathrm{ns}}$ & $0.559 * *$ & $0.553 *$ & $0.501 * *$ & $0.571 *$ \\
\hline$a$ & $0.753 * *$ & $0.725 *$ & $0.982 * *$ & $0.820 * *$ & $0.740 * * *$ \\
\hline$\alpha$ & $1.445 *$ & $1.455 * *$ & $1.378 * *$ & $1.572 * * *$ & $1.428 * *$ \\
\hline $\mathrm{R}^{2}$ & 0.992 & 0.993 & 0.993 & 0.997 & 0.994 \\
\hline \multicolumn{6}{|l|}{$0.65-0.70$} \\
\hline$\theta_{R}$ & $0.276 * *$ & $0.273 * *$ & $0.262 * *$ & $0.263 * * *$ & $0.288 * * *$ \\
\hline$\theta_{S}$ & $0.545 * *$ & $0.553 * *$ & $0.537 * *$ & $0.488 * *$ & $0.549 * * *$ \\
\hline$a$ & $0.338 *$ & $0.364 *$ & $0.299 * *$ & $0.508 * *$ & $0.329 * *$ \\
\hline$\alpha$ & $1.471 * *$ & 1.497 ** & 1.480 * & 1.534 ** & $1.441 * *$ \\
\hline $\mathrm{R}^{2}$ & 0.993 & 0.994 & 0.996 & 0.997 & 0.988 \\
\hline \multicolumn{6}{|l|}{$0.75-0.80$} \\
\hline$\theta_{\mathrm{R}}$ & $0.276 * *$ & $0.258 * *$ & $0.271 * *$ & 0.247 ** & 0.254 * \\
\hline$\theta_{\mathrm{S}}$ & $0.544 * * *$ & $0.553 * *$ & $0.541 *$ & $0.485 * * *$ & 0.491 * \\
\hline $\mathrm{a}$ & $0.293 * *$ & $0.370 * *$ & $0.313 * *$ & $0.419 * * *$ & $0.384 * *$ \\
\hline$\alpha$ & $1.716^{* *}$ & $1.696 * *$ & $1.787 * *$ & $1.842 * * *$ & $1.934 * *$ \\
\hline $\mathrm{R}^{2}$ & 0.996 & 0.995 & 0.993 & 0.998 & 0.993 \\
\hline
\end{tabular}

Treatments: NC = natural Cerrado vegetation; IR = inter-rows of coffee plants intercropped with Brachiaria-grass; FP40 = furrowing to a depth of $0.40 \mathrm{~m}$; FP60 $=$ furrowing and mixing to a depth of $0.60 \mathrm{~m}$; FP80 = furrowing to a depth of $0.80 \mathrm{~m}$ and mixing to a depth of $0.60 \mathrm{~m} . \theta_{\mathrm{S}}=$ water content at saturation $\left(\mathrm{m}^{3}\right.$ $\left.\mathrm{m}^{-3}\right) ; \theta_{R}=$ residual water content $\left(\mathrm{m}^{3} \mathrm{~m}^{-3}\right) ; \alpha$ and $n=$ fitted parameters; $\mathrm{R}^{2}=$ coefficient of determination. Not significant (ns), **** and *** indicate $\mathrm{P}>0.05$, $\mathrm{P}<0.05, \mathrm{P}<0.01$ and $\mathrm{P}<0.001$, respectively.

as those tested in the experiment is, therefore, a relevant contribution to natural resources conservation in the region while representing an important alternative for sustainable crop production.

\subsection{Final infiltration rate}

The FIR results indicate that the volume of relatively large pores was significantly influenced by the equipment used in furrow preparation and in Brachiaria-plantation in the coffee inter-row lanes. These results demonstrate the effectiveness of the management alternatives tested on improving soil structure, notably by reducing surface crusts formation (Fig. 3) and, consequently, by promoting increments in water infiltration from a water potential of $-0.05 \mathrm{~m}$ (Fig. 4). Therefore, the importance of increasing pores larger than $150 \mu \mathrm{m}$ (water potential $>-0.20 \mathrm{~m}$ ) is indirectly emphasized; however, mainly pores of $600 \mu \mathrm{m}$ (infiltration between water potentials of 0.00 and $-0.05 \mathrm{~m}$ ) should be conserved in these soils, as these soils are considered fragile and are highly susceptible to erosion (Santos et al., 1998; Silva et al., 2005; Barbosa et al., 2020).
FIR increase in the planting row has agronomic benefits, as increased rainwater intake directly into coffee plants rhizosphere. It has also environmental benefits, as reduced excess rainfall potentially generating surface runoff on the coffee rows and its propagation downslope to the $3.6 \mathrm{~m}$ inter-row lane, installed parallel to the contour. This reduces risk of soil and water losses by rainfall erosion while increasing opportunities for groundwater recharge (Schneider et al., 2017). Beneficial effects on FIR come also from intercropping with Brachiaria-grass. Up to $-0.20 \mathrm{~m}$ of water potential, IR presented the highest FIR, $175 \%$ higher than that of natural vegetation (NC), which can be explained by grass roots breaking through the dense soil layers (Flávio Neto et al., 2015). Besides, as indicated in the previous section, IR reduced surface crusting, which has direct effects on FIR. As compared to treatments applied, NC showed the lowest FIR in all water potentials tested, seemingly because of surface crusting and this was attributed to the ineffective cover provided by native rupestrian vegetation.

The beneficial effects of Brachiaria-grass on soil structure (Rocha et al., 2016) enable better water movement throughout the biopores (channels created by plant roots), whose improvements have not surpassed only the FP60 and FP80. Flávio Neto et al. (2015), evaluating the potential of biological soil loosening by Brachiaria-grass, observed approximately $50 \%$ physical recovery throughout the entire layer of a degraded soil after 6 months of Brachiaria decumbens cultivation, with frequent cutting. Additionally, this grass also contributed to the formation and stabilization of larger aggregates because of the ample addition of organic matter (Pinheiro et al., 2004; Bronick and Lal, 2005; Beldini et al., 2010). The presence of larger and more stable aggregates also favors soil resistance to erosion, which is of the utmost importance in these Inceptisols, highly prone to erosion (Santos et al., 1998).

It is important to note that the use of grass of the genus in question is already widely adopted as an inter-row cover crop in coffee plantations (Serafim et al., 2013b); this technique results in numerous benefits to the soil (Silva et al., 2015), better development of coffee roots in biopores (Carducci et al., 2014, 2015; Silva et al., 2016) and has no deleterious effects on coffee productivity due to plant competition (Silva et al., 2019), given its frequent control by cutting.

In turn, the relatively high FIR in FP60 and FP80 at 0.00 and $0.05 \mathrm{~m}$ is probably related to the effects of the soil mixer (Table 2), since soil preparation can disrupt restricting soil layers, increasing soil porosity (Schneider et al., 2017; Peixoto et al., 2019, 2020) and increasing water infiltration rate (Singh et al., 2019), thus favoring water movement (Perroux and White, 1988). The benefits presented here justify the deep furrow in shallow Inceptisol for establishment of coffee plantations as compared to a shallower furrowing, which also performs worse than Brachiaria in what regards infiltration rate at all suction heads tested. Brachiaria sp. has a strong root system development, capable of compaction alleviation (Scarabeli et al., 2018) and able to enhance pore connectivity (Galdos et al., 2020). The combined effects of deep tillage induced by subsoiler (which breaks dense soil layers and, by that, improves rooting depth; Singh et al., 2019), with disturbance intensity induced by soil mixer, generates a deep furrow with long-lasting structural loosening effects, thus improving plant-available water use and crop resilience to water stress (Schneider et al., 2017).

\subsection{Spatial variability of soil hydraulic conductivity}

The fitted semivariograms allowed us to identify accentuated spatial dependence throughout the Inceptisol profile, according to the methods of Cambardella et al. (1994). The strong spatial dependence for FP40, FP60, FP80 and NC (SD than $25 \%$ - Fig. 5) indicates the continuity of $K_{0}$ in the different land-use and management systems, while the low spatial dependence in IR stems from the strong nugget effect originating from variation that remained undetected by the sampling. $K_{0} \mathrm{SD}$ values reported in literature are higher in recently tilled agricultural areas (Gülser et al., 2016) than under other land uses at watershed scale (Wang and Shao, 2011). 

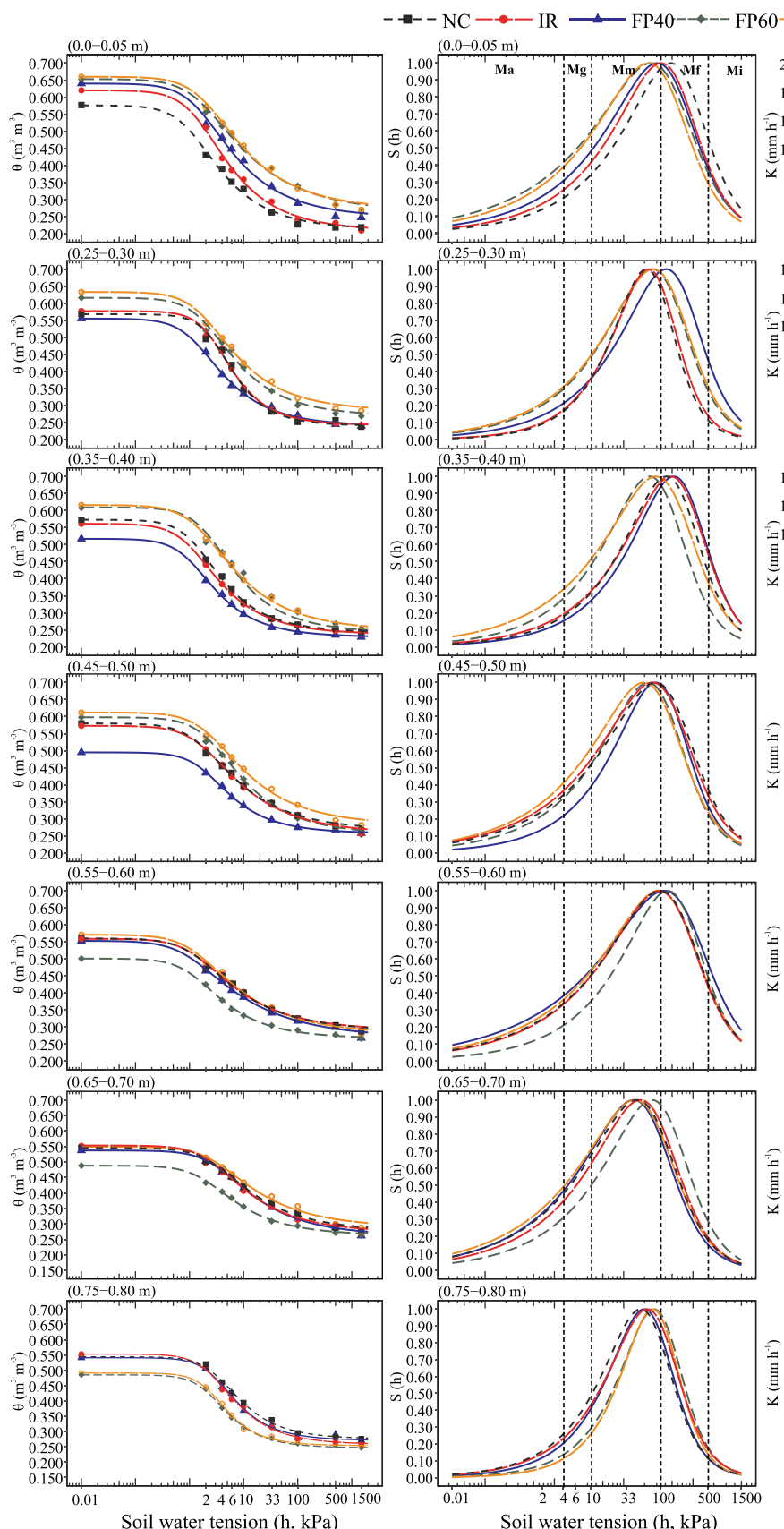

Soil water tension $(\mathrm{h}, \mathrm{kPa})$
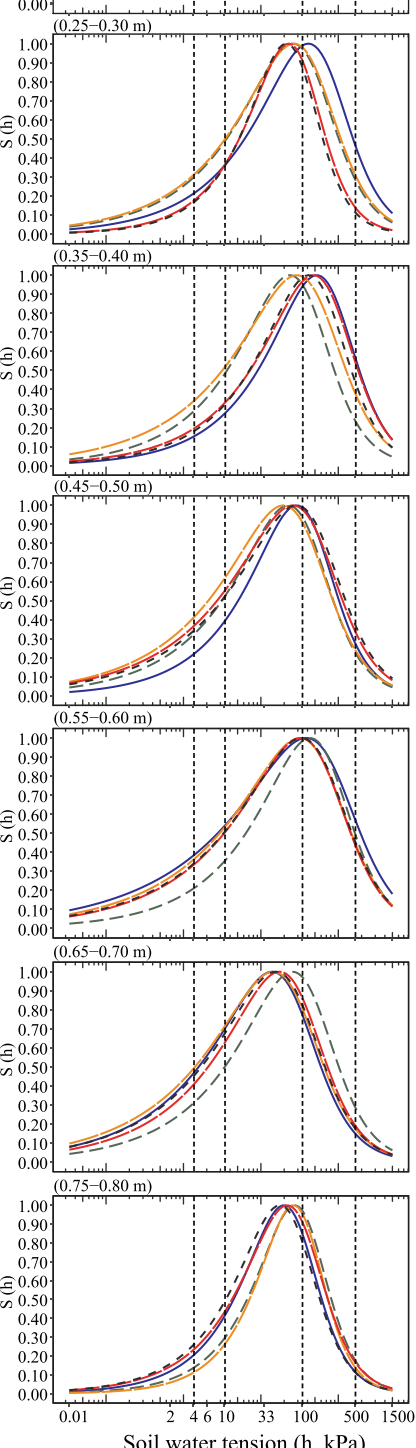

Soil water tension $(\mathrm{h}, \mathrm{kPa})$
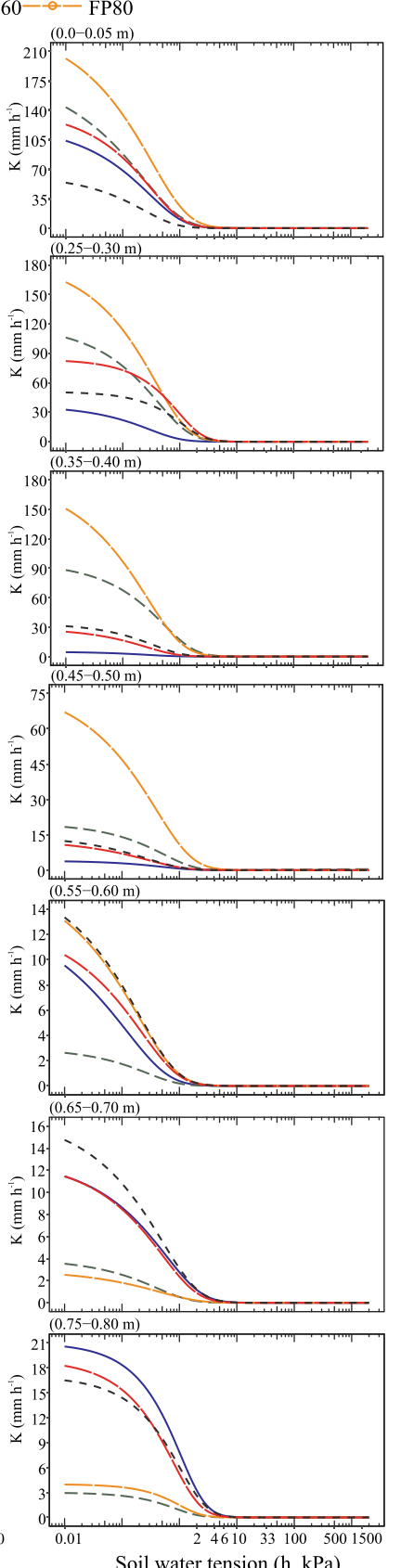

Fig. 7. Soil water retention curves $\left(\theta, \mathrm{m}^{3} \mathrm{~m}^{-3}\right)$, pore size distribution curves [S(h), normalized pore volume] and unsaturated hydraulic conductivity curves $\left(\mathrm{K}, \mathrm{mm} \mathrm{h}^{-1}\right)$ in an Inceptisol Treatments: $\mathrm{NC}=$ natural Cerrado vegetation; IR = inter-rows of coffee plants intercropped with Brachiaria-grass; FP40 = furrowing to a depth of $0.40 \mathrm{~m} ; \mathrm{FP} 60$ = furrowing and mixing to a depth of $0.60 \mathrm{~m}$; FP80 = furrowing to a depth of $0.80 \mathrm{~m}$ and mixing to a depth of 0.60 $\mathrm{m}$. Pore size classification: $\mathrm{Ma}=$ macropores; $\mathrm{Mg}=$ large mesopores; $\mathrm{Mm}=$ medium mesopores; $\mathrm{Mf}=$ fine mesopores; $\mathrm{Mi}=$ micropores.
The higher $K_{0}$ in FP60 (up to $0.25 \mathrm{~m}$ ) and FP80 (up to $0.43 \mathrm{~m}$ ) are related not only to subsoiling but also to soil mixing promoted by the furrow ridger (Table 2), which rearranged soil structure and porosity throughout the disturbed profile so as to outcome increased soil water flux during redistribution. The relationship between macroporosity and $K_{0}$ has been well documented in several studies (Mentges et al., 2010); however, small continuous pores may also conduct water, whereas large discontinuous pores may not contribute much to the soil hydraulic conductivity (Bouma, 1982). Although soil deep mix is expected to prolong residual effects of tillage loosening (Schneider et al., 2017), particle rearrangement sets in and the soil may reconsolidate, due to alternate wetting and drying cycles, over a time-span of 18 months as it is the case of this study. However, the delayed reconsolidation process seemingly occurring in the experimental area, can be explained by the low clay activity of this Inceptisol $\left(\sim 6 \mathrm{cmol}_{\mathrm{c}} \mathrm{kg}^{-1}\right.$ clay, Barbosa et al., 2020), since mineralogy is one of the main factors that interfere in the speed of reconsolidation in tropical soils (Bonetti et al., 2017).

In the FP40, FP60 and FP80 treatments, the $K_{0}$ was very low in the $0.40-0.55 \mathrm{~m}, 0.52-0.75 \mathrm{~m}$ and $0.70-0.80 \mathrm{~m}$ soil layers, respectively. Considering that in NC $K_{0}$ values were higher than those of the treatments for the aforementioned layers (Fig. 6), it is assumed that soil ridging and subsoiling contributed to a drastic reduction in $K_{O}$ at these deeper layers. This is because of subsurface compaction resulting from the high pressures exerted by the implements upon the soil at the bottom of the working depth and the subsoil moisture condition during operations, which has been reported in other studies (Araujo-Junior et al., 2011). Barbosa et al. (2020), also in the same experimental area, identified an increase in $\mathrm{BD}$ and a reduction in porosity in layers below the contact between soil and the implements' cutting tools. Compaction restricts the redistribution of water to the $C$ horizon and, therefore, the groundwater recharge; on the other hand, the low hydraulic conductivity found in the deeper soil layers sampled may contribute to a longer 
water residence time in these layers, thus favoring water storage and availability to coffee plants.

It should also be considered that during heavy rainfall events, the less permeable layers could reach saturation and promote fast saturation of the shallow soil above, therefore generating surface runoff. However, intercropping coffee rows with Brachiaria-grass can mitigate this inconvenience as it may promote lateral water flow from the saturated soil in the row to the more permeable soil of the inter-row, considering coffee planting lines are parallel to the contour. As observed (Fig. 6), the presence of Brachiaria-grass increased $K_{0}$ as compared to NC, and the difference in $K_{0}$ was even higher when comparing IR with FP40, down to $0.60 \mathrm{~m}$. Roots of cover crops, promoting changes in soil pore space, can increase hydraulic conductivity (Carminati et al., 2016). Below $0.60 \mathrm{~m}$ soil depth, $K_{0}$ values in IR were higher than those found in FP60 and FP80, and were similar to those found in NC, further supporting the evidence of subsurface compaction caused by deep furrowing operations during soil preparation for coffee plantation.

The observed differences between the furrow preparation treatments reflect the effects of the equipment adopted (Table 2). The soil conditioning provided by the treatments tested, especially for FP80, which increased the water transmission to a depth of $0.65 \mathrm{~m}$, may also contribute to reducing the risk of water stress during the dry season, which may further translate into productivity gains (Silva et al., 2015).

\subsection{Water retention and soil pore size distribution}

The van Genuchten (1980) sigmoidal equation fits well the data from all conditions tested, with coefficients of determination ranging from 0.988 to 0.999 (Table 4). The fitted parameters of the water retention equation $\left(\theta_{S}, \theta_{R}, \alpha, n\right)$ reflect the effect of the treatments tested on the soil water retention curve, highlighting the parameter $\alpha$ and $n$ were affected by treatment and soil depth. The former $(\alpha)$ is related to the air-entry potential and a lower value indicates a higher amplitude of the potential, while higher values of $n$ correspond to a steeper retention curve (Radcliffe and Šimunek, 2010). Higher values of this parameter were observed in the deeper soil layers and may be related to the reduction in macropores and mesopores below the working depth of the implements used.

The soil water retention curves for the FP60 and FP80 treatments resembled each other because in both treatments a soil mixer was applied (Fig. 7). Operations with this equipment affected mainly the proportion of macropores, which is likely to increase water and air flux, thus favoring root growth of coffee plants (Carducci et al., 2015; Silva et al., 2015). The increased macroporosity in FP60 and FP80 may increase aeration and oxygen diffusion in the roots (Grable and Siemer, 1968). Additionally, the relatively high hydraulic conductivity may contribute to faster drainage, thus reducing the risk of runoff and soil erosion (Mentges et al., 2010), which is in accordance with the final infiltration rate and hydraulic conductivity results presented above.

Additionally, the increased volume of large and medium mesopores in the FP60 and FP80 treatments to a depth of $0.5 \mathrm{~m}$ increases the amount of available water, which may favor crop growth (Carducci et al., 2014; Silva et al., 2015). Carducci et al. (2014) observed that large mesopores $(\varnothing>0.20 \mathrm{~mm}$ ) favor the development of fine roots of coffee plants $(\varnothing \leq 1 \mathrm{~mm}$ ), which assuredly increases water and nutrient uptake, since these pores retain plenty of available water. Some reports state that soil tillage increases the volume of large mesopores (e. g., Bescansa et al., 2006).

As reported by Barbosa et al. (2020), following a study performed in the same experimental area, the application of a deep soil preparer (as in the case of FP60 in this study, see Table 2) promoted soil aeration and water availability, corroborating the results presented and discussed above. The FP80 treatment was very effective at maintaining higher $K$ values to a depth of $0.5 \mathrm{~m}$ (Fig. 7), indicating that the storage water would not only be available but also readily replenished. These phenomena would be a benefit to a depth of $0.5 \mathrm{~m}$ in terms of water retention, pore size distribution and hydraulic conductivity, although these treatments induced subsurface soil compaction in the $0.35-0.55$ $\mathrm{m}, 0.55-0.80 \mathrm{~m}$, and $0.75-0.80 \mathrm{~m}$ layers for FP40, FP60 and FP80, respectively. However, our results show that deep furrowing of shallow soil, as was the case for this Inceptisol, in association with the cultivation of Brachiaria-grass between coffee plant rows presents various advantages addressed in the course of this discussion (even including the $K_{0}$, which is low in subsurface layers).

These changes may positively impact root growth in this naturally dense Inceptisol, with possible effects on crop performance and coffee yields (Barbosa et al., 2020), especially during the crop establishment phase in this study region, where edaphological drought is a serious problem that has been worsening in recent years due to poor rainfall distribution and increased temperatures in consecutive years (Companhia Nacional de Abastecimento (CONAB), 2017; Instituto Nacional de Meteorologia (INMET), 2018). Nevertheless, the time period the beneficial impacts of these tillage practices will last remains to be evaluated for these soils under coffee plantations, particularly for factors associated with the formation of surface crusting (rearrangement and consolidation of particles that promote low FIR), as well as their effects on soil water availability. In addition, the dynamics of soil structure (increased density, reduced pore diameter, hydraulic conductivity and water infiltration) with respect to crop sustainability and yield need to be determined.

Studies on the cultivation of newly established coffee plantations are essential, considering that the first years of development are crucial for expressing the maximum production potential in subsequent years. Thus, this study helps to elucidate the effects of soil preparation and management techniques that improve water movement and increase water retention in shallow and naturally dense soils. With respect to coffee plantations in tropical and subtropical regions, these matters are of considerable importance given the vast area of the globe covered by these soils and because of alternatives needed for the conversion of areas already anthropized, which offer opportunities for setting up sustainable coffee plantations on vulnerable or actually degraded soils.

\section{Conclusions}

The alternatives of deep furrowing tested in this study showed efficiencies proportional to the profile disturbance gradient, improving the coffee plantation root environment, as assessed by attributes describing water dynamics and distribution in the soil profile. Results showed improvements in soil hydrodynamic behavior, with increased water movement and availability to a depth of $0.50 \mathrm{~m}$. However, care should be taken when adopting deep furrowing operations, paying attention to the adequate soil moisture conditions to avoid subsurface compaction and reduction in hydraulic conductivity, detected beneath the working depth of the equipment.

The presence of Brachiaria-grass intercropped between the rows of coffee plants, according to results found in this study, leads to an attenuation of the negative effects on soil water dynamics of a naturally dense layer and of subsurface compaction caused by the pressure applied by the grooving implements operating in the soil. In fact, the presence of Brachiaria-grass increased infiltration capacity and hydraulic conductivity, enabling internal soil drainage through lateral flow, which may seemingly help reducing soil and water losses by surface runoff during intense rains falling over these highly erodible soils. The effectiveness of the vegetation cover in mitigating surface crusting is also highlighted in this study. Thus, the management practices adopted can be considered agronomical and environmentally suitable for the cultivation of coffee in shallow and naturally dense Inceptisols.

\section{Declaration of Competing Interest}

The authors report no declarations of interest. 


\section{Acknowledgements}

To Conselho Nacional de Desenvolvimento Científico e Tecnológico (CNPq) for granting the scholarship and to the funding agencies Coordenação de Aperfeiçoamento de Pessoal de Nível Superior (CAPES), Fundação de Amparo à Pesquisa do Estado de Minas Gerais (FAPEMIG), $\mathrm{CNPq}$, and Consórcio Brasileiro de Pesquisa e Desenvolvimento do Café (CBP\&D/Café) of Empresa Brasileira de Pesquisa Agropecuária - Unidade Café (Embrapa Café). To Universidade Federal de Lavras (UFLA) and Departamento de Ciência do Solo (DCS) for the provided support. To Frade farm for allowing and aiding in the installation of the experiment and to IF Goiano for support of our research.

\section{Appendix A. Supplementary data}

Supplementary material related to this article can be found, in the online version, at doi:https://doi.org/10.1016/j.still.2021.105127.

\section{References}

Araujo-Junior, C.F., Dias Junior, M.S., Guimarães, P.T.G., Alcântara, E.N., 2011. Load bearing capacity and critical water content of a Latossol induced by different managements. R. Bras. Ci. Solo 35, 115-131. https://doi.org/10.1590/S010006832011000100011 (Abstract in English).

Barbosa, S.M., Silva, B.M., Oliveira, G.C., Benevenute, P.A.N., Silva, R.F., Curi, N., Moretti, B.S., Silva, S.H.G., Norton, L.D., Pereira, V.M., 2020. Deep furrow and additional liming for coffee cultivation under first year in a naturally dense Inceptisol. Geoderma 357, 113934. https://doi.org/10.1016/j. geoderma.2019.113934.

Beldini, T.P., Mcnabb, K.L., Lockaby, B.G., Sanchez, F.G., Navegantes-Câncio, O., 2010. The effect of Amazonian Eucalyptus plantations on soil aggregates and organic matter density fractions. Soil Use Manage. 26, 53-60. https://doi.org/10.1111/ j.1475-2743.2009.00248.x.

Bernardes, T., Moreira, M.A., Adami, M., Rudorff, B.F.T., 2012. Physic-environmental diagnosis of coffee crop in the state of Minas Gerais, Brazil. Coffee Sci. 7, 139-151. https://doi.org/10.25186/cs.v7i2.241 (Abstract in English).

Bescansa, P., Imaz, M.J., Virto, I., Enrique, A., Hoogmoed, W.B., 2006. Soil water retention as affected by tillage and residue management in semiarid Spain. Soil Tillage Res. 87, 19-27. https://doi.org/10.1016/j.still.2005.02.028.

Beutler, A.N., Silva, M.L.N., Curi, N., Ferreira, M.M., Cruz, J.C., Pereira Filho, I.A., 2001 Resistance to penetration and permeability of a typic Dystrophic Red Latosol under management systems in the Cerrado region. R. Bras. Ci. Solo 25, 167-177. https:// doi.org/10.1590/S0100-06832001000100018 (Abstract in English).

Bonetti, A.J., Anghinoni, I., Moraes, M.T., Fink, J.R., 2017. Resilience of soils with different texture, mineralogy and organic matter under long-term conservation systems. Soil Tillage Res. 174, 104-112. https://doi.org/10.1016/j. still.2017.06.008.

Borges, L.C., Ferreira, D.F., 2002. Power and type I error rates of Scott-Knott, Tukey and Student-Newman-Keuls's tests under residual normal and non normal distributions. Rev. mat. estat. 21, 67-83 (Abstract in English).

Bouma, J., 1982. Measuring the conductivity of soil horizons with continuous macropores. Soil Sci. Soc. Am. J. 46, 438-441. https://doi.org/10.2136/ sssaj1982.03615995004600020047x.

Bouma, J., 1991. Influence of soil macroporosity on environmental quality. Adv. Agron. 46, 2-37. https://doi.org/10.1016/S0065-2113(08)60577-5.

Bronick, C.J., Lal, R., 2005. Soil structure and management: a review. Geoderma 124, 3-22. https://doi.org/10.1016/j.geoderma.2004.03.005.

Cambardella, C.A., Moorman, T.B., Novak, J.M., Parkin, T.B., Karlen, D.L., Turco, R.F., Konopka, A.E., 1994. Field-scale variability of soil properties in Central Iowa soils. Soil Sci. Soc. Am. 58, 1501-1511. https://doi.org/10.2136/ sssaj1994.03615995005800050033x.

Carducci, C.E., Oliveira, G.C., Curi, N., Rossoni, D.F., Costa, A.L., Heck, R.J., 2014. Spatial variability of pores in oxidic Latosol under a conservation management system with diferente gypsium doses. Ciênc. Agrotec. 38, 445-460. https://doi.org/ 10.1590/S1413-70542014000500004.

Carducci, C.E., Oliveira, G.C., Curi, N., Heck, R.J., Rossoni, D.F., Carvalho, T.S., Costa, A L., 2015. Gypsum effects on the spatial distribution of coffee roots and the pores system in oxidic Brazilian Latosol. Soil Tillage Res. 145, 171-180. https://doi.org/ 10.1016/j.still.2014.09.015.

Carminati, A., Zarebanadkouki, M., Kroener, E., Ahmed, M.A., Holz, M., 2016. Biophysical rhizosphere processes affecting root water uptake. Annals Bot. 118, 561-571. https://doi.org/10.1093/aob/mcw113.

Coelho, E.C., Souza, E.G., Uribe-Opazo, M.A., Pinheiro Neto, R., 2009. The influence of sample density and interpolation type on the elaboration of thematic maps. Acta Sci. Agron. 31, 165-174. https://doi.org/10.4025/actasciagron.v31i1.6645 (Abstract in English).

Companhia Nacional de Abastecimento (CONAB), 2017. Acompanhamento Da Safra Brasileira De Café, v.4 - Safra 2017. n.4..
Conselho dos Exportadores de Café do Brasil (CECAFÉ), 2018. Conselho Dos Exportadores De Café Do Brasil (CECAFÉ). Monthly export statistics - November 2017.

Cressie, N.A., 1993. Statistics for Spatial Data. John Wiley and Sons, New York, p. 900.

Dexter, A.R., 2004. Soil physical quality: part I. Theory, effects of soil texture, density, and organic matter, and effects on root growth. Geoderma 120, 201-214. https:// doi.org/10.1016/j.geodermaa.2003.09.005.

Dexter, A.R., Czyż, E.A., Gaţe, O.P., 2004. Soil structure and the saturated hydraulic conductivity of subsoils. Soil Tillage Res. 79, 185-189. https://doi.org/10.1016/j. still.2004.07.007.

Diggle, P.J., Ribeiro Junior, P.J., 2007. Model Based Geostatistics. Springer, New York, p. 230.

Effgen, T.A.M., Passos, R.R., Andrade, F.V., Lima, J.S.S., Reis, E.F., Borges, E.N., 2012. Physical soil properties as a function of management in crops of conilon coffee. Rev. Ceres 59, 414-421. https://doi.org/10.1590/S0034-737X2012000300018 (Abstract in English).

Figueiredo, T., Poesen, J., 1998. Effects of surface rock fragment characteristics on interrill runoff and erosion of a silty loam soil. Soil Tillage Res. 46, 81-95. https:// doi.org/10.1016/S0167-1987(98)80110-4.

Flávio Neto, J., Severiano, E.C., Costa, K.A.P., Guimarães Junnyor, W.S., Gonçalves, W. G., Andrade, R., 2015. Biological soil loosening by grasses from genus Brachiaria in crop-livestock integration. Acta Sci. Agron. 37, 375-383. https://doi.org/10.4025/ actasciagron.v37i3.19392.

Fox, D.M., Darboux, F., Carrega, P., 2007. Effects of fire-induced water repellency on soil aggregate stability, splash erosion, and saturated hydraulic conductivity for different size fractions. Hydrol. Process. 21, 2377-2384. https://doi.org/10.1002/hyp.6758.

Galdos, M.V., Brown, E., Rosolem, C.A., Pires, L.F., Hallett, P.D., Mooney, S.J., 2020. Brachiaria species influence nitrate transport in soil by modifying soil structure with their root system. Sci. Rep. 10, 5072. https://doi.org/10.1038/s41598-020-61986-0.

Grable, A.R., Siemer, E.G., 1968. Effects of bulk density, aggregate size, and soil water suction on oxygen diffusion, redox potential and elongation of corn roots. Soil Sci. Soc. Am. J. 32, 180-186. https://doi.org/10.2136/ sssaj1968.03615995003200020011x.

Guedes, L.P.C., Uribe-Opazo, M.A., Johann, J.A., Souza, E.G., 2008. Anisotropy to analyze spatial variability of some spatially referenced soil chemical variables. R. Bras. Ci. Solo 32, 2217-2226. https://doi.org/10.1590/S010006832008000600001 (Abstract in English).

Gülser, C., Ekberli, I., Candemir, F., Demir, Z., 2016. Spatial variability of soil physical properties in a cultivated field. Eurasian J. Soil Sci. 5, 192-200. https://doi.org/ 10.18393/ejss.2016.3.192-200.

Instituto Nacional de Meteorologia (INMET), 2018. Instituto Nacional De Meteorologia (INMET). Available in: Andlt; http://www.inmet.gov.br/portal/Andgt (accessed 20 February 2018).

International Union of Soil Sciences (IUSS) Working Group WRB, 2015. World Reference Base for Soil Resources. International Soil Classification System for Naming Soils and Creating Legends for Soil Maps. World Soil Resources Reports No. 106. FAO, Rome.

Kahlon, M.S., Lal, R., Ann-Varughese, M., 2013. Twenty-two years of tillage and mulching impacts on soil physical characteristics and carbon sequestration in Central Ohio. Soil Tillage Res. 126, 151-158. https://doi.org/10.1016/j. still.2012.08.001.

Kautz, T., Amelung, W., Ewert, F., Gaiser, T., Horn, R., Jahn, R., Javaux, M., Kemna, A., Kuzyakov, Y., Munch, J.-C., Pätzold, S., Peth, S., Scherer, H.W., Schloter, M., Schneider, H., Vanderborght, J., Vetterlein, D., Walter, A., Wiesenberg, G.L.B., Köpke, U., 2013. Nutrient acquisition from arable subsoils in temperate climates: a review. Soil Biol. Biochem. 57, 1003-1022. https://doi.org/10.1016/j. soilbio.2012.09.014.

Kirkegaard, J.A., Lilley, J.M., Howe, G.N., Graham, J.M., 2007. Impact of subsoil water use on wheat yield. Aust. J. Agric. Res. 58, 303-315. https://doi.org/10.1071/ AR06285.

Klute, A., 1965. Laboratory measurement of hydraulic conductivity of saturated soil. In: Black, C.A. (Ed.), Methods of Soil Analysis I: Physical and Mineralogical Properties, Including Statistics of Measurement and Sampling. American Society of Agronomy, Madison, pp. 210-221, pp. 13.

Kuhn, N.J., Armstrong, E.K., Ling, A.C., Connolly, K.L., Heckrath, G., 2012. Interrill erosion of carbon and phosphorus from conventionally and organically farmed Devon silt soils. Catena 91, 94-103. https://doi.org/10.1016/j.catena.2010.10.002.

Le Bissonnais, Y., Bruand, A., 1993. Crust micromorphology and runoff generation on silty soil materials during different seasons. In: Poesen, J.W.A., Nearing, M.A. (Eds.), Soil Surface Sealing and Crusting. Catena Supplement, 24, pp. 1-16.

Lima, J.M., Curi, N., Resende, M., Santana, D.P., 1990. Dispersion of soil material in water for indirect evaluation of latosol erodibility. R. Bras. Ci. Solo 14, 85-90 (Abstract in English).

Madsen, M.D., Zvirzdin, D.L., Petersen, S.L., Hopkins, B.G., Roundy, B.A., Chandler, D.G., 2011. Soil water repellency within a burned pinon-juniper woodland: spatial distribution, severity, and ecohydrologic implications. Soil Sci. Soc. Am. J. 75, 1543-1553. https://doi.org/10.2136/sssaj2010.0320.

Medeiros, J.C., Figueiredo, G.C., Mafra, Á.L., Rosa, J.D., Yoon, S.W., 2013. Deep subsoiling of a subsurface-compacted typical hapludult under citrus orchard. Rev. Bras. Ciência do Solo 37, 911-919. https://doi.org/10.1590/S010006832013000400008.

Mellek, J.E., Dieckow, J., Silva, V.L., Favaretto, N., Pauletti, V., Vezzani, F.M., Souza, J.L. M., 2010. Dairy liquid manure and no-tillage: physical and hydraulic properties and carbon stocks in a Cambisol of Southern Brazil. Soil Tillage Res. 110, 69-76. https:// doi.org/10.1016/j.still.2010.06.005.

Mentges, M.I., Reichert, J.M., Rosa, D.P., Vieira, D.A., Rosa, V.T., Reinert, D.J., 2010. Soil physicohydric properties and chisel energy demand in a compacted Alfisol. Pesq. 
Agropec. Bras 45, 315-321. https://doi.org/10.1590/S0100-204X2010000300012 (Abstract in English).

Mualem, Y., 1976. A new model for predicting the hydraulic conductivity of unsaturated porous media. Water Res. Res. 12, 513-522. https://doi.org/10.1029/ WR012i003p00513.

Mucina, L., 2018. Vegetation of Brazilian campos rupestres on siliceous substrates and their global analogues. Flora 238, 11-23.

Oliveira Filho, A.T., Fontes, M.A.L., 2000. Patterns of floristic differentiation among Atlantic Forest in South-eastern Brazil, and influence of climate. Biotropica 32, 139-158. https://doi.org/10.1111/j.1744-7429.2000.tb00619.x.

Peel, M.C., Finlayson, B.L., Mcmahon, T.A., 2007. Updated world map of the KöppenGeiger climate classification. Hydrol. Earth Syst. Sci. Discuss. 11, 1633-1644. https://doi.org/10.5194/hess-11-1633-2007.

Peixoto, D.S., Silva, B.M., Oliveira, G.Cde, Moreira, S.G., da Silva, F., Curi, N., 2019. A soil compaction diagnosis method for occasional tillage recommendation under continuous no tillage system in Brazil. Soil Tillage Res. 194, 104307 https://doi.org/ 10.1016/j.still.2019.104307.

Peixoto, D.S., Silva, L., de, C.M., da Melo, L.B.B., de Azevedo, R.P., Araújo, B.C.L., de Carvalho, T.S., Moreira, S.G., Curi, N., Silva, B.M., Montoani, B., 2020. Occasional tillage in no-tillage systems: A global meta-analysis. Sci. Total Environ. 745 https:// doi.org/10.1016/j.scitotenv.2020.140887.

Perroux, K.M., White, I., 1988. Designs for disc permeameters. Soil Sci. Soc. Am. J. 52, 1205-1215. https://doi.org/10.2136/sssaj1988.03615995005200050001x.

Pinheiro, E.F.M., Pereira, M.G., Anjos, L.H.C., 2004. Aggregate distribution and soil organic matter under different tillage systems for vegetable crops in a Red Latosol from Brazil. Soil Tillage Res. 77, 79-84. https://doi.org/10.1016/j.still.2003.11.005.

Poesen, J., 1985. Surface sealing on loose sediment: the role of texture, slope and position of stone in the top layer. In: Callebaut, F., Gabriels, D., de Boodt, M. (Eds.), Assessment of Soil Surface Sealing and Crusting. Flanders Research Centre for Soil Erosion and Soil Conservation, Ghent, Belgium, pp. 64-71.

Pulido-Moncada, M., Katuwal, S., Ren, L., Cornelis, W., Munkholm, L., 2020. Impact of potential bio-subsoilers on pore network of a severely compacted subsoil. Geoderma 363, 114154. https://doi.org/10.1016/j.geoderma.2019.114154.

R Core Team, 2017. A Language and Environment for Statistical Computing. R Foundation for Statistical Computing, Vienna, Austria. http://www.R-project.org/.

Radcliffe, D.E., Šimunek, J., 2010. Soil Physics With HYDRUS: Modeling and Applications. CRC Press, p. 373.

Resende, M., Curi, N., Rezende, S.B., Corrêa, G.F., 2014. Pedologia: Base Para Distinção De Ambientes, 6.eD. Universidade Federal de Lavras, Lavras, p. 378.

Reynolds, W.D., Drury, C.F., Tan, C.S., Fox, C.A., Yang, X.M., 2009. Use of indicators and pore volume-function characteristics to quantify soil physical quality. Geoderma 152, 252-263. https://doi.org/10.1016/j.geoderma.2009.06.009.

Ribeiro Junior, P.J., Diggle, P.J., 2001. geoR: a package from geoestatistical analysis. RNews 1, 15-18. Available in: http://citeseerx.ist.psu.edu/viewdoc/download? doi=10.1.1.464.3971\&rep=rep1\&type=pdf (accessed December 21th, 2017).

Ritz, C., Streibig, J.C., 2008. Nonlinear Regression With R. Springer Science, p. 151.

Rocha, O.C., Ramos, M.L.G., Veiga, A.D., Silva, E.A., Guerra, A.F., Bartholo, G.F., Rodrigues, G.C., Silva, E., 2016. Chemical and hydrophysical attributes of an Oxiso under coffee intercropped with brachiaria in the Cerrado. Pesq. Agropec. Bras 51, 1476-1483. https://doi.org/10.1590/s0100-204x2016000900046.

Santos, D., Curi, N., Ferreira, M.M., Evangelista, A.R., Cruz, A.B., Teixeira, W.G., 1998. Soil losses and productivity of improved native pastures under different management practices. Pesq. Agropec. Bras. 33, 183-189 (Abstract in English). Available in: https://ainfo.cnptia.embrapa.br/digital/bitstream/item/45020/1/PERDAS-D E-SOLO-E-PRODUTIVIDADE-DE-PASTAGENS.pdf (accessed January $7^{\text {th }}, 2018$ ).

Santos, H.G., Jacomine, P.K.T., Anjos, L.H.C., Oliveira, V.A., Lumbreras, J.F., Coelho, M. R., Almeida, J.A., Araújo Filho, J.C., Oliveira, J.B., Cunha, T.J.F., 2018. Brazilian Soil Classification System, 5.ed. Brasília E-book, Embrapa.

Scarabeli, I.G.R., Tormena, C.A., Favilla, H.S., Figueiredo, G.C., 2018. Field-saturated hydraulic conductivity measured by two techniques and at different sampling positions relative to maize-crop rows and interrows. Semina: Ciênc. Agrár 39, 403-410, 10.5433/1679, https://doi.org/0359.2018v39n1p403.

Schneider, F., Don, A., Hennings, I., Schmittmann, O., Seidel, S.J., 2017. The effect of deep tillage on crop yield - What do we really know? Soil Tillage Res. 174, 193-204. https://doi.org/10.1016/j.still.2017.07.005.
Serafim, M.E., Oliveira, G.C., Lima, J.M., Silva, B.M., Zeviani, W.M., Lima, V.M.P., 2013a. Water availability and landscape distinction for coffee cultivation. Rev. Bras. Eng. Agríc. Ambient. 17, 362-370. https://doi.org/10.1590/S141543662013000400002 (Abstract in English).

Serafim, M.E., Oliveira, G.C., Vitorino, A.C.T., Silva, B.M., Carducci, C.E., 2013b. Soil physical quality and least limiting water range of Latosol and Cambisol under coffee in conservation management. R. Bras. Ci. Solo 37, 733-742. https://doi.org/ 10.1590/S0100-06832013000300020 (Abstract in English).

Sillmann, J., Kharin, V.V., Zwiers, F.W., Zhang, X., Bronaugh, D., 2013. Climate extremes indices in the CMIP5 multimodel ensemble: part 2. Future climate projections. J. Geophys. Res. Atmos. 118, 2473-2493. https://doi.org/10.1002/jgrd.50188.

Silva, A.M., Silva, M.L.N., Curi, N., Lima, J.M., Avanzi, J.C., Ferreira, M.M., 2005. Soil, water, nutrients and organic carbon losses from Inceptisol and Oxisol under natural rainfall. Pesq. Agropec. Bras. 40, 1223-1230. https://doi.org/10.1590/S0100204X2005001200010 (Abstract in English).

Silva, B.M., Oliveira, G.C., Serafim, M.E., Silva, E.A., Ferreira, M.M., Norton, L.D., Curi, N., 2015. Critical soil moisture range for a coffee crop in an oxidic Latosol as affected by soil management. Soil Tillage Res. 154, 103-113. https://doi.org/ 10.1016/j.still.2015.06.013.

Silva, E.A., Silva, S.H.G., Oliveira, G.C., Carducci, C.E., 2016. Root spatial distribution in coffee plants of different ages under conservation management system. Afr. J. Agric. Res. 11, 4970-4978. https://doi.org/10.5897/AJAR2016.11356.

Silva, R.F., Santos, G.G., Nóbrega, J.C.A., Oliveira, G.C., Dias, B.O., Santos, D.P., Silva Júnior, J.P., 2017. Impacts of land-use and management systems on organic carbon and water-physical properties of a Latossolo Amarelo (Oxisol). Semin., Ciênc. Agrár. 38, 109-124. https://doi.org/10.5433/1679-0359.2017v38n1p109.

Silva, R.F., Santos, G.G., Nobrega, J.C.A., Santos, D.P., Silva Junior, J.P., Lustosa Filho, J. F., Oliveira, G.C., Dias, B.O., 2018. Soil use and management systems, time since adoption, and their impacts over aggregation. R. Bras. Ci. Agr. 13, e554. https://doi. org/10.5039/agraria.v13i3a5544.

Silva, B.M., Oliveira, G.C., Serafim, M.E., Silva, É.A., Guimarães, P.T.G., Melo, L.B.B., Norton, L.D., Curi, N., 2019. Soil moisture associated with least limiting water range, leaf water potential, initial growth and yield of coffee as affected by soil management system. Soil Tillage Res. 189, 36-43. https://doi.org/10.1016/j. still.2018.12.016.

Singh, K., Choudhary, O.P., Singh, H.P., Singh, A., Mishra, S.K., 2019. Sub-soiling improves productivity and economic returns of cotton-wheat cropping system. Soil Tillage Res. 189, 131-139. https://doi.org/10.1016/j.still.2019.01.013.

Soil Survey Staff, 2014. Keys to Soil Taxonomy, 12edition. 97. United States Department of Agriculture, Natural Resources Conservation Service, Lincoln, p. 360.

Teixeira, P.C., Donagemma, G.K., Fontana, A., Teixeira, W.G., 2017. Manual of Soil Method Analysis. 3.eD. Rio De Janeiro, p. 573.

Valentin, C., Bresson, L.M., 1992. Morphology, genesis and classification of surface crusts in loamy and sandy soils. Geoderma 55, 225-245. https://doi.org/10.1016/00167061(92)90085-L.

Van Genuchten, M.T., 1980. A closed-form equation for predicting the hydraulic conductivity of unsaturated soils. Soil Sci. Soc. Am. J. 44, 892-898. https://doi.org/ 10.2136/sssaj1980.03615995004400050002x.

Wang, Y.Q., Shao, M.A., 2011. Spatial variability of soil physical properties in a region of the Loess Plateau of PR China subject to wind and water erosion. Land Degrad Dev 24, 296-304. https://doi.org/10.1002/ldr.1128.

Wickham, H., 2009. ggplot2: Elegant Graphics for Data Analysis. Springer, New York, p. 211.

Wiesmeier, M., Hübner, R., Barthold, F., Spörlein, P., Geuß, U., Hangen, E., Reischl, A., Schilling, B., Von Lützow, M., Kögel-Knabner, I., 2013. Amount, distribution and driving factors of soil organic carbon and nitrogen in cropland and grassland soils of southeast Germany (Bavaria). Agric. Ecosyst. Environ. 176, 39-52. https://doi.org/ 10.1016/j.agee.2013.05.012.

Wischmeier, W.H., Smith, D.D., 1978. Predicting Rainfall Erosion losses - a Guide to Conservation Planning. Agriculture Handbook No 537. U. S. Department of Agriculture, Washington, D. C.

Xie, J., Wang, L., Li, L., Coulter, J.A., Chai, Q., Zhang, R., Luo, Z., Carberry, P., Rao, K.P. C., 2020. Subsoiling increases grain yield, water use efficiency, and economic return of maize under a fully mulched ridge-furrow system in a semiarid environment in China. Soil Tillage Res. 199, 104584 https://doi.org/10.1016/j.still.2020.104584. 